\title{
Aulo Gelio y la literatura española del Siglo XVI: autor, texto, comentario y relectura moderna ${ }^{1}$
}

\author{
Francisco García Jurado \\ Universidad Complutense
}

\section{RESUMEN}

Se analiza en este trabajo las referencias a Aulo Gelio en los autores españoles del siglo XVI, en particular Fray Antonio de Guevara, Pedro Mejía, y Cristóbal de Villalón. Asimismo, se recurre puntualmente a importantes comentarios sobre Gelio y la miscelánea que encontramos en Michel de Montaigne y Luis Vives. Se revisan los datos a la luz de las referencias al autor antiguo como tal, el interés temático de sus citas, los comentarios críticos a la obra y su relectura moderna, miscelánea o ensayística.

Palabras clave: Aulo Gelio, Literatura española del siglo XVI, Fray Antonio de Guevara, Pedro Mejía, Cristóbal de Villalón, Montaigne, antología, miscelánea, ensayo

\section{Aulus Gellius and 16th century spanish literature: author, text, commentaries and new readings}

\begin{abstract}
This paper will analyse the references to Aulus Gellius made by Spanish authors in the 16th century, with special attention to Fray Antonio de Guevara, Pedro Mejía and Cristóbal de Villalón. Likewise, this study will refer to some significant commentaries about Gellius and the miscellanea present in Michel de Montainge's and Luis Vives' works. The data will be reviewed in the light of the references to the ancient author himself, as well as to the thematic interest of his quotations, the critic commentaries to his work, and its modern re-reading, in terms of miscellanea or essay.
\end{abstract}

Key Words: Aulus Gellius, XVIth, Century Spanish Literature, Fray Antonio de Guevara, Pedro Mejía, Cristóbal de Villalón, Montaigne, anthology, miscelanea, essay

${ }^{1}$ El presente estudio se inscribe en el Grupo UCM 930136 "Historiografía de la Literatura Grecolatina en España” y en el proyecto de investigación FFI2010-14963, financiado por el Ministerio de Ciencia e Innovación. 


\section{INTRODUCCIÓN}

Los libros que componen las Noches áticas de Aulo Gelio (s. II) responden a la plasmación física de una idea dinámica de la literatura, pues suponen un conjunto variopinto de lecturas, audiciones y recuerdos organizados con aparente libertad dentro de una miscelánea. Su fama posterior, su difusión en otras obras, a manera de citas, comentarios o relecturas, presenta la misma naturaleza que dio lugar a la obra en sí. De esta forma, los libros de Gelio serían tanto el fruto de una variada escritura, la del propio autor, como de una lectura intensa y rica por parte de otros autores posteriores. Cabe preguntarse, sin embargo, cómo pudo ser ese proceso de lectura en España durante la Edad Moderna, ya que las Noches áticas no se traducen al castellano hasta finales del siglo XIX, concretamente en 1893, momento en que se abre una nueva página de las lecturas de Gelio en castellano, como hemos tenido ocasión de estudiar en otro lugar (García Jurado 2008, p. 58). Sin embargo, su aparición en la literatura española, si bien discreta, en comparación con otros grandes autores de la Antigüedad, es constante, y da prueba de que hay un conocimiento de la obra por parte de autores como Fray Antonio de Guevara o Pedro Mejía, que contribuyen, asimismo, a su difusión indirecta. Así pues, el carácter misceláneo de la obra de Gelio, su naturaleza de obra abierta, de recopilación de escritos varios, también se deja ver en la propia recepción moderna. Es un libro destinado a personas eruditas, de ahí la no necesidad de una traducción hasta pasados muchos siglos. Cabe preguntarse si el estudio de la huella de sus lecturas en la literatura española nos permitiría llevar a cabo una antología ("antología inminente", como diría Alfonso Reyes) de una parte significativa de las historias y noticias que aparecen en la obra latina. Si esto fuera posible, cabría hablar, por tanto, de una forma de traducción implícita de la obra, que unos leen y narran para que otros la conozcan a través de sus lecturas. Puede darse, asimismo, el fenómeno de que un autor que cite a Gelio no lo haya leído directamente, sino a través de otros autores. Este es uno de los resortes esenciales del funcionamiento de la antología.

Hay varias razones que apuntan a ver en el siglo XVI un momento dorado de la lectura de Aulo Gelio no sólo en España sino también en Europa, en particular debido a dos hechos notables: (a) de una parte, lo que va a ser una primera edición bien difundida y provista de notas críticas, precisamente la de Stephanus; (b) de otra parte, el salto cualitativo de la miscelánea al ensayo, que podemos encontrar ya cristalizado en la lectura de Michel de Montaigne, y cuyo nuevo planteamiento ensayístico nace de una progresiva reacción contra la propia miscelánea humanista. Es oportuno que desarrollemos brevemente ambos aspectos:

(a) Gracias a la imprenta, el texto de Aulo Gelio gozó de una gran difusión y se convirtió en una lectura propiamente humanista. Entre otras cosas, 
Gelio no es ajeno al hecho de que sean precisamente los buenos autores los que comiencen a llamarse "clásicos" (Luck 1958). La invención de la imprenta da lugar a una sucesión numerosa de ediciones. Dado que se trata de un texto misceláneo que sirve para muchos usos, las ediciones totales y parciales crecen de una manera notable ya en el siglo XVI. Habrá que llegar a la fundamental edición parisina de Stephanus (1585), a la que a veces acompañan las notas de Luis Carrión, para disponer del primer hito moderno en la edición de Gelio².

(b) Conviene superar el concepto de "fuente" y, más que plantear la posible influencia de Gelio en el ensayo moderno, considerar cómo la modernidad ha releído su obra a manera de precursora de esta misma modernidad, desde la paradoja que supone superar al autor antiguo para fundar nuevas formas de escritura. Se trata, pues, de averiguar cómo se ha considerado la obra de Gelio desde las nuevas claves literarias del siglo XVI, en particular de la moderna literatura ensayística (Gómez 1996, p. 41 y García Jurado 2007a, p. 18).

Desde tales presupuestos, nuestro propósito es llevar a cabo un primer acercamiento de conjunto a la lectura de Gelio en la literatura castellana del siglo XVI utilizando el Corpus Diacrónico del Español de la Real Academia Española a partir de la voz "Gelio"3. Obtenemos, de esta forma, 220 datos, cifra significativa si la comparamos con el resto de ejemplos en los otros siglos:

1400-1500: 0 casos en 0 documentos 1501-1600: 220 casos en 34 documentos 1601-1700: 67 casos en 28 documentos 1701-1800: 16 casos en 11 documentos 1801-1900: 15 casos en 9 documentos 1901-2000: 5 casos en 3 documentos

Es pertinente completar esta búsqueda con los otros nombres por los que tradicionalmente se ha conocido a nuestro autor, a saber, las voces "Agelio" (14 casos desde 1422 a 1754) y "Aulogelio" (9 casos desde 1521 a 1605), si bien para este trabajo no las vamos a recoger ${ }^{4}$. De esta forma, hemos obteni-

\footnotetext{
${ }^{2}$ A este respecto, cabe citar aquí la anotación que hace Menéndez Pelayo (1950: 373375 ) en su afán por defender la aportación hispana al acervo científico, cuando destaca la importancia de las notas a Gelio elaboradas por Luis Carrión (Ludovicus Carrio) e incluidas en las ediciones de Henricus Stephanus (París, 1585): "El texto castigado y enmendado por Carrión y Stéphano fué reproducido muchas veces: sirvió de base al de Gronovio, vulgarizado en muchas ediciones elzevirianas (la primera de 1651), y todavía fué utilizado en la hermosa edición Variorum de 1706, que es la más importante de las antiguas".

${ }^{3}$ REAL ACADEMIA ESPAÑOLA: Banco de datos (CORDE) [en línea]. Corpus Diacrónico del Español. <http://www.rae.es> [Fecha de la consulta: 20 de noviembre de 2009]. Hacemos una acotación cronológica que va de 1501 a 1600.

${ }^{4}$ Asimismo, en el Corpus del Español Actual (CREA) aparecen seis casos con la voz "Gelio", desde 1986 a 2004, de los que dos datos no responden al autor latino.
} 
do una relación casi completa, si bien aproximada, de datos obtenidos en tal corpus, y que nos remiten a referencias explícitas al propio autor de las $\mathrm{No}$ ches áticas de acuerdo al siguiente esquema: número de datos obtenidos / año de la obra / autor / título / publicación: editor moderno / editorial (ciudad), año de edición. La lista resultante queda como sigue:

1/1590/Álava de Viamont, Diego/El perfecto capitán/Cristina/Blas Nistal, CILUS (Salamanca), 2000

12/1542/Anónimo/Baldo/Folke Gernert/Centro de Estudios Cervantinos (Alcalá de Henares), 2002

6/1571/Anónimo/Traducción de la Imagen de la vida cristiana de Fray Héctor Pinto/Edward Glaser/ Juan Flors (Barcelona), 1967

15/c 1550/Arce de Otárola, Juan de/Coloquios de Palatino y Pinciano/José Luis Ocasar Ariza/ Turner (Madrid), 1995

2/1592-a 1631/Argensola, Bartolomé Leonardo de/Rimas/José Manuel Blecua/ CSIC (Zaragoza), 1951

2/a 1598/Cabrera, Fray Alonso de/Consideraciones sobre los Evangelios de los domingos de Adviento/Bailly-Baillière (Madrid), 1906

1/a 1598/Cabrera, Fray Alonso de/De las consideraciones sobre todos los evangelios de la Cuaresma/Miguel Mir/Bailly-Baillière (Madrid), 1906

13/1527-1550/Casas, Fray Bartolomé de las/Apologética historia sumaria/Vidal Abril Castelló et alii/Alianza Editorial (Madrid), 1992

1/1513/Encina, Juan del/Égloga de Plácida y Vitoriano/Miguel Ángel Pérez Priego/Cátedra (Madrid), 1991

2/1535-1557/Fernández de Oviedo, Gonzalo/Historia general y natural de las Indias/Juan Pérez de Tudela Bueso/Atlas (Madrid), 1992

3/1569/Franco, Francisco/Tractado de la nieve y del uso de ella/María Teresa García García/CILUS (Salamanca), 2000

8/1521-1543/Guevara, Fray Antonio de/Epístolas familiares/José María de Cossío/ Real Academia Española (Madrid), 1950-1952

2/1539/Guevara, Fray Antonio de/Menosprecio de corte y alabanza de aldea/Asunción Rallo/Cátedra (Madrid), 1984

9/1529-1531/Guevara, Fray Antonio de/Reloj de príncipes/Emilio Blanco/Turner (Madrid), 1994

1/ a 1582/Gurrea y Aragón, Martín de/Discursos de medallas y antigüedades/José Ramón Mélida/Impr. Viuda e hijos de M. Tello (Madrid), 1902

3/1600/Gutiérrez de los Ríos, Gaspar/Noticia general para la estimación de las artes/Alegría Alonso González, CILUS (Salamanca), 2000

3/1580/Herrera, Fernando de/Comentarios a Garcilaso /Antonio Gallego Morell/ Gredos (Madrid), 1972

5/1570-1579/Horozco, Sebastián de/Libro de los proverbios glosados/Jack Weiner/ Reichenberger (Kassel), 1994

5/1599/Huerta, Jerónimo de/Traducción de los libros de Historia natural de los animales de Plinio/CORDE/Real Academia Española (Madrid), 2004

4/1528/Justiniano, Juan/Instrucción de la mujer cristiana, de J.L. Vives/Elizabeth Teresa Howe/Fundación Universitaria Española (Madrid), 1995

45/1540-c 1550/Mejía, Pedro/Silva de varia lección/Antonio Castro/Cátedra (Madrid), 1989-1990

3/1585/Pérez de Moya, Juan/Philosofía secreta de la gentilidad/Carlos Clavería/ Cátedra (Madrid), 1995 
48/1589/Pineda, Juan de/Diálogos familiares de la agricultura cristiana/Juan Meseguer Fernández/Atlas (Madrid), 1963-1964

1/1587/Poza, Andrés de/De la antigua lengua, poblaciones y comarcas de las Españas/Ángel Rodríguez Herrero/Ediciones Minotauro (Madrid), 1959

1/1595/Ribadeneira, Pedro de/Tratado de la religión y virtudes que debe tener el príncipe cristiano para gobernar sus estados/Vicente de la Fuente/Biblioteca de autores españoles (Madrid), 1868

1/c 1545/Sanz, Pedro Luis/Trecientos proverbios/Mónica Pauner Chulvi; José Luis Canet/Universidad de Valencia (Valencia), 2001

2/1544/Saravia de la Calle, Luis/Instrución de mercaderes muy provechosa.../Cristina Blas Nistal/CILUS (Salamanca), 2000

1/1566/Timoneda, Juan de/El Patrañuelo/M ${ }^{a}$ Pilar Cuartero Sancho/Espasa-Calpe (Madrid), 1990

9/1548/Toro, Gabriel de/Tesoro de misericordia divina y humana/Lina Rodríguez Cacho; Mariano Quirós García/CILUS (Salamanca), 1999

1/1569/Toro, Luis de/Discursos o consyderaciones sobre la materia de enfriar la bevida en que se tracta de las differentias.../Jacobo Sanz Hermida/Ediciones de la Universidad de Salamanca (Salamanca), 1991

3/1569/Torquemada, Antonio de/Jardín de flores curiosas/Lina Rodríguez Cacho/ Turner (Madrid), 1994

2/c 1553-1556/Villalón, Cristóbal de/El Crótalon de Cristóforo Gnofoso/Asunción Rallo/Cátedra (Madrid), 1990

2/c 1539/Villalón, Cristóbal de/El Scholástico/Richard J. A. Kerr/CSIC (Madrid), 1977

3/1594/Villegas, Alonso de/Fructus sanctorum y quinta parte del Flos sanctorum/ Josep Lluis Canet Vallés/LEMIR (Valencia), 1988.

Hemos tomado de la lista anterior tan sólo autores que ya habíamos revisado previamente para otros trabajos: Fray Antonio de Guevara, Pedro Mejía, y Cristóbal de Villalón. Son autores que representan, respectivamente, la epístola, la miscelánea y el diálogo renacentista, si bien no de manera exclusiva. Asimismo, hemos añadido tres autores más: Gabriel de Toro (en atención a sus referencias a la humanitas), Pérez de Moya, y Antonio de Torquemada, que completan aspectos no recogidos por los anteriores autores. También hemos recurrido a un importante texto latino de Luis Vives escrito como dura crítica contra Gelio, habida cuenta de la importancia específica que tiene para entender la introducción a las Noctes publicada por Stephanus, donde éste ataca al autor español. Asimismo, recurriremos a otro autor francés, Michel de Montaigne, tanto para valorar las raras citas directas que hace de Gelio en sus Ensayos como las referencias implícitas en las que Pedro Mejía ha sido el intermediario entre ambos autores ${ }^{5}$. Se trata, por tanto, de una selección provisional que deberá ser completada en el futuro. Quedan, asimismo, al margen varios problemas de naturaleza cualitativa sobre la cita de Gelio:

5 "La silva di varia leccion de Pedro di Mexia, publiée incomplètement en 1542, eut un très vif succès; l'édition de Madrid 1576 se donne comme la dixième. Elle était traduite en italien dès 1544. La traduction française de Gruget, publiée en 1552, fut bientôt augmentée du cinquième livre et eut de nombreuses éditions. Il semble bien que Montaigne ait possédé l'une d'elles, bien qu'il soit difficile de le démontrer d'une manière absolue". (Villey, 1908: 177). 
- Referencias implícitas, rastreables cuando el autor moderno trata un tema recogido por Gelio, que ha podido servir de fuente.

- Es difícil valorar a menudo si se ha manejado directamente al autor latino o si proviene de referencias indirectas.

- También hay dificultad a la hora de valorar la veracidad de las citas, sobre todo cuando en éstas se da una mezcla de lectura e invención (el problema ha sido tratado por Holford-Strevens 2005, p. XI y Heath 2008, p. 301).

A partir de estos datos, ensayaremos una tipología de las referencias a Gelio en torno a cuatro criterios ya establecidos en otros trabajos relativos al estudio de los autores antiguos en las literaturas modernas ${ }^{6}$, a saber:

2.1. AUTOR. La presentación y caracterización de la persona que encarna al autor de las Noches áticas, por ejemplo como "filósofo" o "historiador".

2.2. TEXTO. Citas y paráfrasis: antología de textos. Es pertinente hacer notar cuándo se cita el libro y capítulo concreto de la obra de Gelio.

2.3. COMENTARIO. Juicios expresados en las obras modernas sobre aspectos literarios o pedagógicos que conciernen a las Noches áticas, como el valor de la erudición.

2.4. RELECTURA MODERNA. Se trata de la cuestión más genérica y cualitativa: cómo pasa la antigua miscelánea a ser releída en clave moderna bien de miscelánea, bien de ensayo. Este rasgo es el más complejo, pues no presenta unas marcas concretas y supone un trascendental salto epistemológico.

Esta tipología ${ }^{7}$ nos permitirá hacer un recorrido por las referencias a la obra de Gelio donde podremos observar diferencias cualitativas relevantes a partir de los datos obtenidos.

\section{La lectura de Gelio en el Siglo XVI español: aUtor, teXto, CO- MENTARIO Y RELECTURA}

\subsection{Autor: la caracterización de Aulo Gelio}

En lo que respecta a la representación de la figura del autor antiguo entre los modernos, hay que partir de la misma caracterización indirecta que Gelio hace de sí mismo al poner a su obra el título de Noctes Atticae (Vardi 1993):

\footnotetext{
${ }^{6}$ Para el criterio de relaciones intertextuales que seguimos cf. García Jurado 2007a, pp. 20-25.

${ }^{7}$ A título de ejemplo, es muy significativo observar cómo dentro de la literatura argentina del siglo XX el poeta Arturo Capdevila recrea la persona de Aulo Gelio en el poema que lleva el mismo título, Julio Cortázar inserta un texto de las Noches áticas en su novela miscelánea Rayuela, Bioy Casares comenta de manera elogiosa que la obra de Gelio constituye uno de esos libros que estimulan la inteligencia, y, finalmente, Borges relee la noticia erudita de una paloma de madera que vuela en calidad de moderno relato fantástico (García Jurado, 2008).
} 
con ello pretende, ante todo, representarse ante sus lectores como un estudioso, en la tranquilidad nocturna ${ }^{8}$. La figura del erudito trabajado durante la noche supone ya desde los tiempos antiguos la actividad que llamamos "elucubración". La imagen ha pervivido a través de los tiempos hasta el punto de que la relectura humanista de esta misma figura ha quedado plasmada gráficamente en el siglo XVII, como vemos en el frontispicio de la fundamental edición geliana de Gronovius (1688), donde aparece Gelio ataviado como un personaje contemporáneo junto a Apolo, dentro de un estudio presidido por una imagen de Minerva. Por su parte, el mismo Pedro Mejía se ve a sí mismo como si fuera un nuevo Aulo Gelio cuando habla de sus "vigilias" al comienzo de la Silva de varia lección. Teresa Callejas (1996) considera con acierto que Mexía evoca de manera metaliteraria las "noches" de Gelio cuando utiliza la palabra "vigilia" para hablar de su obra, y da la impresión de que hasta se identifica con el autor latino:

"Por lo qual yo, preciándome tanto de la lengua que aprendí de mis padres como de la que me mostraron preceptores, quise dar estas vigilias a los que no entienden los libros latinos (...)" (Mejía, Silva de varia lección I, pp. 163-164).

Sin embargo, esta cándida imagen del erudito comienza a ser objeto de rechazo, a tenor de lo que leemos en el mismo Montaigne, quien critica de manera genérica a los eruditos que pasan parte de la noche en vela ${ }^{9}$ :

"Y ese otro tan pituitoso, legañoso y sucio, al que ves salir de estudiar pasada la medianoche, ¿crees que busca en los libros la forma de llegar a ser más digno, más sabio y más feliz? Ni hablar. En estas morirá, o enseñará a la posteridad la medida de los versos de Plauto y la ortografía correcta de una palabra latina". (Montaigne, Ensayos I, 39, p. 267).

Este texto supone la importante tensión que se establece entre la mera erudición, acumulativa e impersonal, y el ensayo como reflexión propia. Será una tensión a la que volveremos al final de este trabajo, cuando hablemos

${ }^{8}$ Cf. Vardi 1993 y Ker 2004, p. 212: «The nocturnal writing scene would seem to lack the opportunities for social communication that exist in the recitatio. But the nocturnal writer in our examples of Gellius, Seneca, and Pliny is not left unwitnessed: the writer uses a gesture of description precisely to bring himself before the eyes of his audience in the process of writing, and thereby to "maintain a personal relationship" with them». Asimismo, el propio Gelio había hecho recreaciones de personas de autores, como cuando evoca una anécdota relativa a Plutarco (Gel. 1, 26), circunstancia que elogia enormemente uno de sus más conspicuos lectores, Michel de Montaigne: "Los escritos de Plutarco, si se saborean bien, desvélanle bastante, y creo conocer incluso su alma; aún así, querría que tuviéramos algunas memorias de su vida; y heme lanzado a esta divagación apartada a propósito de lo agradecido que le estoy a Aulo Gelio por habernos dejado por escrito esa anécdota de sus costumbres que vuelve al tema de la cólera". (Montaigne, 2003: 31, 708).

${ }^{9}$ Véase a este respecto el comentario que Burke hace de esta crítica desde los presupuestos de la historia cultural (Burke, 1985: 19). 
precisamente sobre la relectura de Gelio en clave de miscelánea moderna. Desde este punto de vista, la caracterización de Gelio como filósofo, historiador o sabio en las alusiones que a él se hacen es un hecho relevante por lo que conlleva de consideración moderna del propio autor latino ante sus nuevos lectores. Asimismo, podemos comparar estas caracterizaciones con la que hace el propio Montaigne, que parece considerar a Gelio de manera implícita como "gramático" cuando habla de la representación que hace de sí mismo ante su público lector:

"Danse a conocer los autores al pueblo por alguna marca particular y externa; yo soy el primero en dar a conocer mi ser total, en mostrarme como Michel de Montaigne, no como gramático, o poeta, o jurisconsulto. Si se queja el mundo de que hablo demasiado de mí, quéjeme yo de que él no piense solo en sî". (Montaigne, Ensayos III, 2, p. 787) ${ }^{10}$.

Montaigne no querría ser, en todo caso, lo que representa Gelio, de forma que el autor moderno se definiría claramente por la negación del antiguo. Luis Vives, por su parte, incluye a Gelio peyorativamente entre los philologi (quorum appellatio est et maxime propria philologi) ${ }^{11}$. De esta forma, la caracterización del autor conlleva a menudo su inclusión dentro de una clase, de un grupo mayor. Por ello, sería pertinente estudiar también la inclusión de Gelio en listas de autores antiguos y modernos. Así las cosas, en este apartado debemos registrar las caracterizaciones que se hacen de Gelio mediante dos criterios básicos, a saber: (a) las denominaciones que recibe en calidad de "historiador", "filósofo", etc. y (b) su inclusión entre autores que presentan características comunes a él. Para terminar este apartado revisaremos, además, (c) la presencia puntual de algún dato biográfico del propio Gelio en el corpus estudiado.

(a) En lo que respecta a las caracterizaciones de Gelio, ya hemos visto cómo Vives lo califica de philologus, mientras que Montaigne lo tilda de "gramático". Sin embargo, Fray Antonio de Guevara lo llama "filósofo" dentro de una enumeración de otros tantos, y así también lo hace Villalón:

“(...) el filósofo Aulo Gelio escribió de lo poco que comían y mucho menos que dormían en las escuelas de su maestro Suborino; el filósofo Plutarcho escribió de las mujeres que hubo en Grecia sabias y de las que hubo en Roma castas". (Guevara, Menosprecio de corte y alabanza de aldea, pp. 242-243).

"Asi como lo hizieron estos que dixe: y Macrobio y Laerçio / Democrito / y Aulo Gelio: y otros muchos philosophos". (Villalón, El Scholástico, p. 9).

Hay que tener en cuenta, naturalmente, qué se quiere decir cuando se utiliza la palabra "philósopho" ("amante del saber") en el siglo XVI, que no tiene la especificidad que hoy le conferimos, y que resulta menos arrogante que el

\footnotetext{
${ }^{10}$ Cf. Heath 2008, p. 315.

${ }^{11}$ Libro III del De tradendis disciplinis (Vives, 1785: 337).
} 
uso del término "sabio"12. Sin embargo, Cristóbal de Villalón habla también de Gelio entre los "sabios antiguos":

"Este estilo y orden tuvieron en sus obras muchos sabios antiguos endereçados en este mesmo fin. Como Ysopo y Catón, Aulo Gelio, Juan Bocacio, Juan Pogio florentín; y otros muchos que sería largo contar, hasta Aristóteles, Plutarco, Platón”. (Villalón, El Crótalon de Cristóforo Gnofoso, pp. 83-84).

(b) Gelio aparece de manera natural junto a antiguos autores de ciencia y erudición, sobre todo con Plutarco y Plinio el Viejo ${ }^{13}$, si bien el grupo puede ampliarse a otros eruditos como los compiladores Solino y Valerio Máximo:

"Loan y nunca acaban de loar Plutarcho y Aulo Gelio y Plinio al buen romano Marco Porcio". (Guevara, Menosprecio de corte y alabanza de aldea, p. 101)

"Pero ni este Marco Sergio ni otro alguno de los romanos no alcançó ni meresció tantas como Lucio Sicinio Dentato, tribuno que fue de la [misma] plebe, que arriba nombramos; del qual escriven los mismos auctores (Plinio, Solino, y también Valerio Máximo y Aulo Gelio) (...)”. (Mejía, Silva de varia lección II, p. 229).

También aparece junto a historiadores como Dionisio de Halicarnaso, Herodiano y de nuevo Plutarco, como vemos en Pérez de Moya, mientras que Mejía, por su parte, habla de Gelio "y otros muchos historiadores":

"Quien largamente quisiera saber de los sacrificios y templo de Vesta, lea a Dionisio Halicarnaseo y a Aulo Gelio, y a Herodiano y a Plutarco. Dicen que Vesta fue amada de Príapo". (Pérez de Moya, Philosofía secreta de la gentilidad, p. 354) "Auctor es de lo dicho Plinio, libro XXXVI, y Pomponio Mela, en el primero, y Herodoto, en el séptimo. Haze memoria deste sepulchro Strabón, en el libro XIV, y Aulo Gelio y otros muchos historiadores". (Mejía, Silva de varia lección II, p. 246).

Asimismo, en las enumeraciones donde entra Gelio caben también los humanistas modernos:

"Y Plinio dize que Eumenes, en la ciudad de Pérgamo, hizo otra a competencia désta. Aulo Gelio y Amiano Marcelino dizen que tenía sietecientos mil libros la librería de Egypto de Alexandría; y Séneca dize casi el mismo número. Y, aunque paresce el número excessivo, quien huviere leýdo los gastos [y] grandezas sin cuento de los reyes de Egypto en los obeliscos y pyrámides y en los templos y hedificios y en las naves y galeras de grandeza inestimable (de las quales cuentan algunas Budeo, en las Annotaciones de las Pandetas, y Lázaro Bayfo, De re navali), no terná esto por impossible". (Mejia, Silva de varia lección II, p. 26).

${ }^{12}$ Dice Covarrubias (1994, s.v. "Filósofo") que "El primero que se intituló con este nombre fue Pitágoras, pareciéndole que el nombre de sabio absolutamente era arrogante, presupuesto que ningún hombre sabe tanto que no le falte mucho que saber. Y de allí adelante todos los profesores de la filosofía no se llamaron sofistas, sino filósofos y por donaire dejaron el nombre de sofistas a los que sabían poco y presumían mucho con doctrinas aparentes y falsas".

${ }^{13}$ Lerner señala que no es casualidad que en el proemio y prefacio de la Silva de Mejía aparezca el trío formado por Plutarco, Gelio y Plinio el Viejo (Lerner, 1989: 491). 
(c) Finalmente, si bien no hay muchos aspectos de la vida de Gelio que transciendan en los textos que estudiamos, conviene señalar dos que han llegado a tener características definidoras de nuestro autor, a saber, su condición de discípulo y amigo del filósofo galo Favorino y la severa crítica que hace al filósofo hispano-latino Séneca. Ambas se encuentran en Fray Antonio de Guevara, tanto en lo referente a Favorino ("Phabormo [sic, por Phaborino], el philósopho, maestro y amigo que fue de Aulo Gelio, dezía muchas vezes que por esso fueron tenidos en tanto los philósophos antiguos, porque avía muy pocos que enseñassen y muchos que deprendiessen". Guevara, Reloj de Príncipes, "Argumento", p. 70), como en lo que concierne a la crítica de Séneca (Gel. 12, 2), que se integra dentro de una copiosa enumeración de autores también reprendidos:

"Muy antigua pestilencia es todas las obras virtuosas aver quien murmure dellas, y en esta regla no sólo entran los que las obran, mas aun los que las escriven, y parece esto ser verdad porque Sócrates fue reprehendido de Platón, Platón de Aristótiles, Aristótiles de Avenruyz, Secilio de Vulpicio, Lelio de Varrón, Marino de Tolomeo, Ennio de Oracio, Séneca de Aulo Gelio, Crastonestes de Estrabo, Thésalo de Galieno, Hermágoras de Cicerón, Cicerón de Salustio, Orígenes de Hierónimo, Hierónimo de Rufino, Rufino de Donato, Donato de Prósper, y Prósper de Lupo. Pues en estos varones tan heroycos y en sus obras cupo correpción, los quales fueron lumbre del mundo, no es por cierto mucho que quepa en mí, sabiendo como sé tan poco". (Guevara, Reloj de príncipes, "Argumento", p. 75).

Nótese el gusto por la enumeración, tan propio de la miscelánea, que resulta una forma de representación acumulativa de autores que con el tiempo llegarán a ser parte de la moderna historia literaria, si bien ya ordenados de manera cronológica o por géneros. Esta crítica que Gelio hace de Séneca será la que motive un duro ataque contra Gelio por parte de Luis Vives, como veremos en el apartado 2.3.

\subsection{Texto: la antología inminente}

La lectura de las Noches Áticas se plasma, de manera explícita o implícita, en los modernos textos misceláneos y epistolares. Esta circunstancia invita a pensar en la posibilidad de llevar a cabo una antología de Gelio construida a partir de tales lecturas. El grado de asimilación del texto latino en el texto moderno presenta niveles distintos que van desde la mera aparición del texto geliano como cita ajena hasta la total apropiación por parte del nuevo autor que lo utiliza. La referencia a Gelio aparece a menudo como criterio de autoridad (el lado contrario sería cuando esta referencia al autor desaparece). Pero cabe asimismo el uso complejo, incluso irónico, de un material ajeno. También es interesante considerar el lugar que esta erudición ocupa en la cultura humanística, novedoso en un principio, como ha señalado Lerner 
(1989), si bien se va produciendo un paulatino agotamiento. Así lo vemos en una de las pocas referencias explícitas que Montaigne hace de Gelio, donde el autor francés cuestiona la autoridad de tales citas:

"Mas yo, que desconfío tanto de la mano como de la boca de los hombres, y que sé que tan poco juiciosamente se escribe como se habla y que estimo tanto este siglo como otro pasado, cito tan contento a un amigo mío como a Aulo Gelio o a Macrobio, y lo que he visto como lo que han escrito". (Montaigne, Ensayos III, 13, p. 1027).

Nótese, además, en este texto un dato implícito que es fundamental: Gelio y (su continuador) Macrobio son esgrimidos como autores prototípicos e ideales para el recurso a la cita (Heath 2008, p. 308), hecho que propicia su lectura atomizada. Vamos a ensayar una clasificación necesariamente convencional de los pasajes relevantes de las Noches áticas que son objeto de cita y lectura en los textos modernos aquí revisados. Atenderemos a los seis criterios siguientes: a) Aforismos y enseñanzas ejemplares; b) Filósofos; c) Cuestiones linguísticas; d) Historia e instituciones; e) Cuestiones médicas y f) Sucesos naturales y extraordinarios. Veamos cada uno de ellos:

(a) Aforismos y enseñanzas ejemplares. La moda del aforismo que recorre la literatura europea del siglo XVI no deja al margen ni tan siquiera al mismo Gelio. Una de sus máximas más difundidas, "La verdad es hija del tiempo" (Gel. 12,11,7), también aparece citada por Guevara:

"Viniendo, pues, al propósito, no nos podemos quexar los que somos agora como se pudieran quexar muchos de los que fueron antes, pues la verdad, la qual dize Aulo Gelio ser hija del tiempo en este postrero tercio del mundo, nos aya declarado muy por estenso todos los errores de que nos hemos de guardar y todas las verdaderas doctrinas que hemos de seguir". (Guevara, Reloj de príncipes, "Argumento", p. 68).

Asimismo, si bien hay muchos pasajes gelianos citados con un propósito formativo y moral, merece la pena que señalemos, precisamente, el crucial concepto de humanitas (Gel. 13, 17) desde la perspectiva de los autores del siglo XVI:

"El vulgo comúnmente (dize Aulo Gelio) llama humanidad el amor y voluntad que un hombre tiene de ayudar y socorrer a otro, por ser de su propia naturaleza, la qual provoca y mueve que se hagan bien unos a otros; (...) latinos y oradores llamaron humanidad (según Aulio Gelio) a la doctrina y erudición de buenas letras, cuya ocupación y exercicio conviene a solo el hombre entre todos los animales, y por esso se llama humanidad y humanistas los que la estudian". (Toro, Tesoro de misericordia divina y humana, fol. CXXVIIv y CXXVIIr).

Tales máximas están dentro de unos ideales educativos a los que no son ajenos los grandes humanistas, como es el caso de Erasmo cuando compila y explica sus Adagia. El hecho de que el hábito no haga a alguien filósofo, con la enseñanza moral que esto conlleva, es un tema muy geliano (Gel. 9, 2), pero 
también un asunto universal que se resume con el dicho de que "el hábito no hace al monje". Encontramos dos lecturas diferentes de este mismo episodio en Gabriel de Toro y Villalón, respectivamente:

“(...) Por lo qual, estando muchos sabios juntos (según Aulo Gelio refiere), llegó un pobre pidiendo para comprar pan, y preguntado quién era, respondió indignado: “¿No véys en mi trage que soy philósopho?". Los que allí estavan dixeron: "Éste es un vagabundo que nunca sale de bodegones, pero deshonraros ha si no le damos; démosle como hombres y no como a hombre con que compre para treynta días pan". (Toro, Tesoro de misericordia divina y humana, fol. CXXVIIIv).

"Cuenta del Aulo Gelio en el nono libro de las noches atticas que estando (sc. Herodes Ático) vn dia en consulta con sus amigos llego a ellos vn peregrino con vna vestidura larga / y la barba hasta la çinta / los cauellos mal atauiados y descalzo: y demando a aquellos varones que estauan con el prinçipe que le diessen vn dinero para comer. Y Herodes le pregunto: di hombre tu quien eres? El peregrino con voz soberuia y con los ojos ayrados le respondio: no me conosces que soy philosopho: por que preguntas lo que claro te muestra el habito y conuersaçion? Dixo Herodes: amigo yo veo la barba y vestidura / mas no veo philosopho: ruegote mucho que me digas que argumentos y señales terne yo para conoscer que vno es philosopho / porque veo tu cara y no tus costumbres? El que verdaderamente se puede llamar philosopho no ha de ser conoscido por el habito y aparençia sino por las obras (...)" (Villalón, El Scholástico, pp. 86-87).

(b) Filósofos. Al igual que ocurre con las vidas de los filósofos narradas por Diógenes Laercio, la obra de Gelio es también un lugar abonado para encontrar anécdotas varias conjugadas con enseñanzas. Modernamente, René Marache sostuvo en la introducción de su edición de las Noches áticas una nueva forma de lectura de la obra de Gelio desde la perspectiva de la llamada "diatriba cínico-estoica", que entiende en la recopilación de tales anécdotas, recuerdos y enseñanzas varias una proyección filosófica que va más allá de la anécdota y representa el estado de la filosofía en los tiempos de Gelio ${ }^{14}$. A resultas de todo esto, son muchos los filósofos que aparecen en Gelio, griegos y latinos. Destaca cómo Mejía contrapone la interpretación de Gelio y Tertuliano ante el hecho de que Demócrito se arrancara los ojos (Gel. 10, 17):

"Deste Demócrito dize también Tertuliano, en el capítulo último de su Apologético, que se quebró los ojos por escusar de no ser tentado de la concupicencia de la carne que, por ver alguna muger, se suele causar; Aulo Gelio dize que lo hizo por poder mejor darse a la contemplación". (Mejía, Silva de varia lección I, p. 496).

"Grande cosa fue la déstos; pero, como se vieron sin vista, la fuerça y necessidad es muy industriosa; esforçáronse contra la falta y hizieron grande effeto. Pero la del philósopho Demócrito, el que de todo se reýa, es más de maravillar; porque, según Cicerón, él mismo se quebró y sacó los ojos para mejor contemplar las cosas naturales, diziendo que le destruýan lo que vía. Lucrecio, poeta, y Aulo Gelio y

${ }^{14}$ Marache (2002). Tras esta cuestión está el asunto más delicado del llamado "humanismo geliano", propuesta por el mismo Marache, y que más recientemente ha sido revisada en profundidad por Holford-Strevens (2005: p. 42). 
otros también lo cuentan ansí; pero yo más me atengo a lo que Tertuliano dize: que es averlo hecho por reprimir su carne, porque la vista de las mugeres lo movían a desonestidad”. (Mejía, Silva de varia lección II, p. 418).

Demóstenes, a quien hoy reconocemos como orador famoso, es recordado como discípulo de Platón (Gel. 3, 12):

"Aulo Gelio, en el tercero libro, capítulo xii, dize que el divino Platón, entre los otros discípulos que tuvo, fue uno el gran philósopho Demóstenes, el qual fue muy estimado de los griegos y muy desseado de los romanos, porque era en su vida muy áspero y en su lengua y doctrina satírico". (Guevara, Reloj de príncipes, "Prólogo general”, p. 25).

Entre las anécdotas más famosas relativas a Demóstenes debe señalarse ésta de la meretriz Laida (Gel. 1, 18):

"Después que Layda volvió de las guerras de Italia a Grecia, retráxose a vivir en la ciudad de Corintho, y fué allí tan servida y requestada, que no hubo hombre rico en Asia que a sus puertas no llamase, ni quedó rey ni príncipe que allá no entrase. Aulo Gelio dice que el buen philósopho Demóstenes fué una vez disfrazado desde Grecia a Corintho por la ver, y aun con ella se revolver; y como ella, antes que le abriese la puerta, le enviase a pedir docientos sestercios de plata, respondió Demóstenes: «No quieran los dioses que yo gaste mi hacienda, ni aventure mi persona, en cosa que apenas la habré hecho, cuando della esté arrepentido». Esto pienso que dixo Demóstenes, por lo que dice el Philósopho, es a saber: «Quod omne animal post coitum tristatur»." (Guevara, Epístolas familiares I, ep. 63, p. 395).

Es notable el añadido final con el que concluye el episodio, donde Guevara acude al "philósopho" por antonomasia, Aristóteles, para conferir a la anécdota una ingeniosa coda. Véase, además, cómo la anécdota va indisociablemente unida a una sentencia del filósofo, de la misma manera que vemos en esta otra sobre Diógenes (Gel. 11, 18):

"Fue una vez preso Diógenes por ciertos cosarios atenienses, y en su captiverio nunca perdió el ánimo ni las palabras libres. Poniéndolo en almoneda aquél cuyo captivo era, para lo vender, le preguntó el pregonero que lo avisasse qué abilidad tenía, para que la publicasse. Respondió el Diógenes: — «Di que vendes un siervo que sabe mandar y governar a los libres». Gelio y Macrobio escriven que esta respuesta dio [a] Xeniades, que fue el que lo compró y lo hizo después maestro de sus hijos". (Mejía, Silva de varia lección I, p. 404).

Por su ejemplaridad, destacan las cartas dirigidas a Aristóteles transcritas por Gelio. Una de ellas es la carta del rey Filipo a Aristóteles (Gel. 9, 3) para comunicarle el nacimiento de Alejandro:

"Pues, viniendo a las hystorias, excelente rey y capitán fue Filipo, rey de Macedonia; pero, conformándose con este parecer, aviendo sabido que le era nacido su hijo Alexandre y biviendo en Athenas en su tiempo Aristótiles, luego embió una breve, pero muy notable carta; la qual, según que Plutarco y Aulo Gelio 
escriven, dezía las palabras siguientes: "Filipo dize a Aristóteles salud. Hágote saber, Aristóteles, que me ha nacido un hijo, por el qual doy a Dios muchas gracias; y no tanto por su nascimiento, quanto por avérmelo dado en tu tiempo [y vida]. Porque tengo esperança [que], siendo por ti criado y doctrinado, saldrá y será tal, que merezca el nombre de mi hijo y la sucessión de mi reyno y estado". (Mejía, Silva de varia lección II, p. 72).

Y otra carta importante es la que Alejandro envía a Aristóteles para quejarse de que éste haya publicado sus enseñanzas (Gel. 20, 5):

"Por lo que Plutarco y Aulo Gelio y Temistio y otros escriven que, andando él en la guerra y conquista de Asia, supo (sc. Alejandro Magno) cómo Aristóteles avía publicado ciertos libros de natural philosophía que dél avía él oýdo; y sintiólo y pésole tanto, que luego le embió una carta en que dezía las palabras siguientes: «Por cierto, Aristótiles, mal lo has hecho en publicar los libros de philosophía especulativa que escreviste. ¿En qué te paresce a ti que excederé yo a los otros hombres, si aquellos estudios y artes que tú me enseñaste a mí comiençan a ser comunes a todos? Hágote saber que yo en sciencia y dotrina querría antes hazer ventaja que en riquezas y poder». Fue menester que Aristóteles le respondiesse que avía escripto los libros tan obscuros, que nadie los podía entender, si él no se los declarasse". (Mejía, Silva de varia lección II, p. 74).

Conforme a lo que sería la diatriba filosófica en los tiempos de Gelio, Favorino, su maestro, argumenta para justificar con qué tipo de mujer hay que casarse (Gel. 5, 11):

"En lo que toca a la hermosura y gesto de la muger, Faborino, philósopho, según escrive Aulo Gelio, dezía que el hombre devía de casar con muger que ni sea muy hermosa ni tampoco [fea], sino de mediano y razonable gesto. Lo qual él dezía respondiendo a otro philósopho que quería fundar que no se deven los hombres casar y hazía un argumento falso, diziendo desta manera: — «El hombre se ha de casar con muger fea o con hermosa; si con hermosa, es andar a peligro y tener muger para otro; e, si con fea, es tormento y pena ordinaria; y, pues ambas cosas son malas, que lo bueno era no casarse». A lo qual, entre otras respuestas que Aulo Gelio escrive, pone la de Favorino: que no es forçoso que ha de ser fea o muy hermosa la muger, que medio ay entre estas dos cosas; puede hombre casar con muger de bueno y razonable gesto y assí se libraría destos dos peligros.

Esto dezía este philósopho; pero, del mi parescer, no dexará de buscar el hombre la muger hermosa y bien dispuesta, porque el gesto hermoso paresce que naturalmente todos lo aman; y, aunque a esto no tenga fin, teniendo respecto a los hijos, paresce que se deve procurar muger hermosa, pues por la mayor parte le parescen los hijos". (Mejía, Silva de varia lección I, pp. 623-624).

Resulta muy interesante el último párrafo de la cita, por lo que supone de enmienda personal del autor moderno con respecto a lo que dice el antiguo, lo que conlleva una visión propia, de carácter independiente, que apunta sin saberlo a un planteamiento ensayístico más que meramente erudito.

(c) Cuestiones lingüísticas. A pesar de que los problemas que conciernen al lenguaje constituyen una de las partes más significativas de la obra de Gelio, en los autores revisados no hemos encontrado, sin embargo, demasiadas refe- 
rencias a estos aspectos. Las cuestiones gramaticales tampoco parecen ser muy frecuentadas por el ensayista Montaigne, aunque sí conviene destacar que algunas de sus reflexiones acerca de "decir mentira" y "mentir" ("Des menteurs", Ensayos I, 9) están inspiradas en la versión francesa del texto que Pedro Mejía había dedicado a la mentira y que parte, a su vez, de Gelio $(11,11)$ :

"Pero, porque no todos lo entienden bien, declaremos agora la diferencia y distancia que puede aver entre dezir mentira y mentir, y en quántas maneras puede ser, pues Aulo Gelio y otros de más autoridad se preciaron de tratarlo y es cierto que no es siempre todo uno. Y, para mejor entenderse, se sepa primero que mentir es afirmar o negar el hombre algo al contrario de lo que siente o tiene por verdad; y el que ansí no lo hiziere, no se podrá dezir que miente. Passa, pues, desta manera: que puede uno afirmar una mentira, pensando que es verdad; y éste tal dize mentira, pero no miente, porque no haze contra lo que siente y cree. (...) refiere Aulo Gelio que dezía Publio Nigidio que el buen hombre deve hazer de manera que no mienta, y el prudente y sabio cómo no diga mentira. Pero, a mi juyzio, también deve el bueno procurar lo mismo; porque no basta que uno piense que dize verdad en lo que afirma, sino que mire lo que dize y ponga diligencia en saber si es cierto". (Mejía, Silva de varia lección II, pp. 483-484).

Así pues, este pasaje de Mejía, en su versión francesa, sirvió de fuente a Montaigne (Heath 2008, p. 315) a la hora de confeccionar un ensayo temprano, el titulado precisamente "Des menteurs":

"No falta razón cuando se dice que aquel que no se siente bastante seguro de su memoria no ha de meterse a mentiroso. Si bien que los gramáticos distinguen entre decir mentira y mentir; y dicen que decir mentira es decir cosa falsa mas considerando uno mismo que es verdadera; y que la definición de la palabra mentir en latín, de donde nació nuestro francés, implica ir contra la conciencia y por consiguiente solo atañe a aquellos que hablan contra lo que saben, a los cuales me refiero". (Montaigne, Ensayos I, 9, 78).

Es posible observar el tránsito sutil desde el mero comentario gramatical hasta el planteamiento ensayístico.

(d) Historia, instituciones y costumbres. Era de esperar que este aspecto fuera el más recurrente a la hora de citar a Aulo Gelio, dado su carácter de anticuario. En este sentido, Guevara intenta extraer una lectura moral a partir de una de las anécdotas históricas que atribuye a Gelio ${ }^{15}$ :

“Aulo Gelio cuenta, que como en el Senado Romano debatiesen sobre qual de dos capitanes embiarían a la guerra de Panonia, llegando el voto a Catón Censorino, dixo: De los dos que dizes, yo quito el voto a Pulio el moço, aunque es mi deudo, porque nunca le he visto venir descalabrado de la guerra, y veolo andar oliendo por Roma. [fol. 235]". (Guevara, Epístolas familiares II, ep. 42, p. 825).

Por su parte, Pedro Mexía se siente interesado cuando Gelio compara, en

${ }^{15}$ No hemos logrado identificar el texto. 
la línea de las vidas paralelas de Plutarco, a Alejandro con Escipión acerca de la continencia (Gel. 7, 8):

"Después de los abominables hechos y vicios del maldito Heliogábalo, bien será contar algún acto virtuoso de otros príncipes, para quitar el mal sabor que nos han dexado los suyos. Entre los otros hechos que de Alexandre Magno y de Scipión Affricano, el que venció a Anníbal, se cuentan, de cada uno dellos se escrive un muy notable acto de continencia y templança, muy semejante el uno al otro y ambos muy de notar y alabar. De los quales Aulo Gelio haze un problema o pregunta, comparándolos entre sí, dexándolos en dubda y quistión quál de los dos aya sido de mayor punto y perfición en la virtud de la continencia”. (Mejía, Silva de varia lección I, p. 722).

El asunto de la vejez, desde diferentes ángulos, atrae especialmente la atención de Guevara. Este es el caso de los siguientes ejemplos, que comienzan con una cita acerca de la honra de la vejez en la antigua Roma y la veneración a los ancianos (Gel. 2, 15):

"Aulo Gelio (le. II, cap. XV) dice que acerca de los antiquísimos romanos no daban tanta honra, ni eran tenidos en tanta reverencia los que en la república eran ricos, ni los que en el Senado eran generosos, como los que eran en la edad viejos y en la gravedad reposados. En aquellos antiguos siglos eran en tanta veneración tenidos los hombres viejos, que casi como a dioses los honraban, y que en igual de propricios padres los tenían". (Guevara, Epístolas familiares II, ep. 36, p. 769)

"Aulo Gelio, en el segundo libro De noctibus acticis, dize que fue costumbre entre los romanos antiguos de honrar y tener en gran veneración a los viejos, y era ésta tan inviolable ley entre ellos, en que ninguno que fuesse generoso en sangre, ni que fuesse poderoso en riquezas, ni que fuesse venturoso en vencer batallas, podía preceder a los muy viejos ya cargados de canas, por manera que como a dioses los adoravan y como a sus padres los honravan". (Guevara, Reloj de príncipes III, 17, p. 778-779).

El asunto del año climatérico, al que volveremos más adelante, es también pertinente cuando Guevara habla de Marco Aurelio (Gel. 15, 7):

"Murió de edad de sessenta y tres años, en el año climatérico, que es a los lxiii, do la vida humana corre grave peligro, porque allí se cumplen ix sietes o siete nueves. Haze desto un capítulo Aulo Gelio en el libro De noctibus aticis". (Guevara, Reloj de príncipes I, 1, p. 93).

Guevara combina ahora el asunto de la edad con el del reparto entre viejos y mancebos en la antigua Roma, según el rey Tulio Hostilio (se equivoca Guevara, pues se trata en realidad de Servio Tulio) (Gel. 10, 27):

"Aulo Gelio, libro x, capítulo xxvii, dize que Tulio Hostilio, rey que fue de los romanos, acordó de contar todos los viejos y mancebos que avía en el pueblo, y sobre averiguar quáles se llamarían infantes, y quáles se llamarían moços, y quáles se llamarían viejos, uvo no poca contienda entre los philósophos romanos. Finalmente determinóse por el rey y por el Senado que los hombres hasta los dezisiete 
años se llamassen infantes, y hasta los quarenta y seys se llamavan moços, y que desde los quarenta y siete se llamassen viejos". (Guevara, Reloj de príncipes III, 18, pp. 783-784).

Mejía antepone a este asunto de las edades la noticia de la división en cinco clases del pueblo romano por parte del rey Servio Tulio (Gel. 10, 28):

"Como fue el de Servio Tulio, rey de Roma, que no tuvo respecto sino al bien común, según cuenta Aulo Gelio en el libro décimo de sus Noches áticas, quando dividió el pueblo romano en aquellas cinco clases o estados. En lo que tocava a las hedades, en solas tres partes dividió la vida del hombre: desta manera, los dezisiete años primeros hizo [o] señaló por puericia o niñez; y de aý adelante, hasta quarenta y seys, los tuvo por ábiles para la guerra y los hizo escrevir y empadronar; y, desde quarenta y seys adelante, los llamó seniores y hombres de consejo. Y esta división de Servio Tulio no contradize a los otros, porque es universal, que incluye las otras particulares y menores". (Mejía, Silva de varia lección I, p. 528).

Encontramos también citas de textos diversos relativos a aspectos morales, jurídicos, militares o anécdotas históricas en general sobre el pueblo romano. Comenzamos con una ley romana que compensaba por un acto de esfuerzo (Gel. 9, 16):

"El mismo Aulo Gelio, en el postrero capítulo del nono libro, escrive otro pleyto o argumento semejante al ya dicho, refiriendo a Plinio, que lo cuenta. Y es assí: que avía en una ciudad una ley que concedía, al que hiziesse un tal acto de esfuerço y fortaleza, le fuesse dado una cosa qualquiera que él pidiesse. Y hizo, pues, uno este hecho; y pidió, por la ley, la mujer de un otro y fuele dada. Después, aquél a quien fue quitada, hizo el mismo hecho y tornó a pedir su muger, con dezir: - «Si a ti te agrada la ley, por ella me has de bolver mi muger; y si no quieres la ley, dámela, pues es mía». El otro le respondió lo mismo: «Si a ti te agrada la ley, por ella la tengo yo, no soy obligado a dártela; y si no te agrada, no tienes título para quitármela, pues ya es mía». Éstos son los casos. Agora los lectores platiquen sobre ello". (Mejía, Silva de varia lección I, p. 341).

Asimismo, la orden de despachar negocios y socorrer a los necesitados aproxima la virtus romana a la cristiana, según recoge Gabriel de Toro:

"La orden que tenían los romanos en despachar negocios y socorrer a los necessitados era (según Aulio Gelio escrive) preferir los niños a las otras personas todas, y después dellos a las mugeres. Y assí devrían hazer los christianos, que proveyessen primero a los niños y mugeres pobres". (Toro, Tesoro de misericordia divina y humana, fol. LXIIIr).

Toro también muestra que en Roma no se perdona la pereza, como tampoco la desobediencia, según ilustra el caso de Tito Manlio (Gel. 9, 13, 20) que cita Mejía:

“(...) no fueron los romanos poco curiosos persiguiendo la ociosidad con rigurosos castigos. No perdonavan (dize Aulio Gelio) al que hallavan mal barvechadas las heredades, viñas o huertas por labrar, por ser argumento de negligencia o 
descuydo. Y más adelante añade cómo castigaron a uno porque tenía flaco el cavallo y no bien curado; el qual, preguntado: "¿Cómo tienes flaco el cavallo, estando tú gordo?", respondió "A mí cúrome yo mismo, y al cavallo, mi moço". Otro, acusado delante de los censores, esperezóse o bostezó, y penáronle por ello, pareciéndoles señal de hombre descuydado y floxo, hasta que juró que no avía sido en su mano. Lo dicho es de Aulo Gelio". (Toro, Tesoro de misericordia divina y humana, fol. LXXIXr).

"Y de aquesta manera se davan y essecutavan otras penas y castigos, que dexo porque no fue agora mi intento sino de escrevir las mercedes [y] galardones. Pero podrálas [muy] bien entender y creer el que ha leýdo cómo no solamente por huyr y mostrar cobardía les davan pena de muerte, pero aun por el esfuerço y valentía, si eran contra el precepto y mandamiento del capitán. De lo qual es [muy] buena prueva aquel riguroso y cruel castigo del cónsul Tito Manlio (del qual escrive Tito Livio, en el octavo libro de la primera década, y también Valerio Máximo y Aulo Gelio), que cortó la cabeça a su hijo porque, contra su prohibición y mandado, vino a batalla con los enemigos, aunque los avía vencido y avía sido provocado y desafiado. En los tiempos de agora, assí como ay [mucha] falta en las mercedes [y] galardones honrras, assí ay también descuydo y remissión en la disciplina y castigo". (Mejía, Silva de varia lección II, pp. 232-233).

Es importante que reparemos aquí en la reflexión final sobre el presente ("agora"), para poner en contraste los hechos contados por Gelio con los vividos en tiempos de Mejía.

Dentro de las costumbres romanas está el asunto de quiénes eran los que iban a las guerras (Gel. 16, 10):

"Pero entre romanos no yvan a la guerra viejos ni sacerdotes (dize Apiano), sal-
vo contra franceses, ni los pobres; porque (según Apiano) antiguamente los que
yvan a la guerra avían de pelear a su costa. Y también dize Aulo Gelio que no
yvan sino los ricos, porque dexavan muger, hijos y hazienda en rehenes y prenda
que los obligava a pelear más que a los necessitados, por lo qual no los admitían
sino en rebates o alborotos acelerados, o a falta de gente. Pero agora es al revés:
que las guerras más son a costa de los pobres y que poco tienen, que no de los
ricos que mucho tienen". (Toro, Tesoro de misericordia divina y humana, fol.
CXXXIIIr).

Aquí hay también una interesante reflexión final sobre el presente ("agora"), hecho que indica muy bien cuál es el alcance de la cita de Gelio, no sólo como testimonio de lo que ocurría en la Antigüedad, sino también como contrapunto con respecto a lo que ocurre en el presente. Siguiendo con la línea de los temas militares tenemos también estas referencias más concretas a la ovación $(\mathrm{Gel} .5,6,21)$ y a las insignias y coronas (Gel. 5, 6, 1-4):

"Huvo destos triumphos en la ciudad de Roma trezientos y veynte, según cuenta Paulo Orosio. Y el postrero que en Roma triumphó, yendo ya el Imperio en diminución, fue el emperador Probo. Usávase también en Roma otra manera de rescebimiento solemne, que era menos que triumpho, a quien llamavan ovación; el qual se dava por las victorias, según dize Aulo Gelio, quando faltava alguna de las calidades que tenemos dicho que se requerían por el triumpho". (Mejía, 1989-1990: II, 209). 
"Pero digamos agora, en particular, de estas insignias y coronas y por qué cosa se davan cada una dellas; que, por ventura, no desagradará al lector esta antigüedad. Las coronas, pues, porque de éstas digamos primero, eran muchas y tenían diversos nombres, y assí, grados y excelencias: avía corona obsidional, corona triumphal y corona oval y cívica y mural y naval y castrense. Plinio tracta de ellas, en el libro diez y seys y veynte y dos, y Aulo Gelio, en el quinto libro". (Mejía, Silva de varia lección II, p. 223).

Hay, asimismo, otras referencias históricas relativas al mundo antiguo, como la de la primera librería pública en Atenas (Gel. 6, 17):

"En Grecia todos affirman que el primero que hizo librería pública fue Pisístrato, tirano de Atenas; la qual fue multiplicada y acrescentada por los athenienses. Pero, sucediendo la venida de Xerxes y entrando en Athenas, mandó tomar todos los libros y llevarlos a Persia, aunque, después de mucho tiempo, el rey Seleuco, llamado Nicátor, los recobró y los hizo tornar y restituyr a Athenas. Assí lo cuenta Aulo Gelio, [en] el libro sexto, y san Ysidoro, donde arriba. Y esta librería fue después en grande augmento acrescentada". (Mejía, Silva de varia lección II, p. 26).

También llaman la atención, como ya hemos tenido ocasión de ver en la historia de la meretriz Laida, curiosidades relativas a las mujeres públicas en la Antigüedad o los ladrones (Gel. 11, 18, 16-17):

"Plutarco y Aulo Gelio dicen que ningún mancebo romano podía entrar a las mugeres públicas sino llevaban las caras bien cubiertas, y si por caso alguno era tan desvergonzado que osase entrar o salir de allí descubierto, tan públicamente era castigado como si cometiera algún forçado adulterio". (Guevara, Epístolas familiares I, ep. 31, p. 185).

"Y otras naciones suffrían a los ladrones y no les davan ningún castigo por ello, como fueron los egypcios, según escrive Aulo Gelio en el libro onze de sus $\mathrm{No}$ ches áticas; y lo mesmo escrive allí de los lacedemonios muy antiguos: que permitían el saltear y hurtar a los mancebos porque se hiziessen muy diestros y ardides contra los enemigos en la guerra". (Mejía, Silva de varia lección II, p. 174).

El episodio de Artemisia y Mausolo (Gel. 10, 18) o la noticia de un famoso templo (Gel. 2, 6, 18) nos lleva al relato de las maravillas de la Antigüedad:

"Y passa desta manera: que Artemisa fue muger de un rey de Caria, provincia en Asia la Menor, llamado Mausoleo; la qual (según cuenta Aulo Gelio, en el dezeno libro de sus Noches, y otros auctores) amó a su marido en tanto grado, que todos hazen maravillas dello y lo ponen por muy notable exemplo. Murió su marido en vida della y hizo llantos y sentimientos nunca vistos; y, assí, le quiso hazer sepulchro conforme al amor que le tenía, y fue tal, que es puesto entre nuestras siete maravillas". (Mejía, Silva de varia lección II, p. 245).

"Este templo, tal y tan grande qual está dicho, se le antojó a un mal hombre de le poner fuego y assí lo hizo; y, siendo preso, confessó que lo avía hecho no por más de porque quedasse fama dél. Y dize Valerio Máximo, en el título «De la cobdicia de la fama», y Aulo Gelio, en el libro segundo, que fue mandado con grandes premias que nadie escriviesse su nombre, porque no consiguiesse la fama que avía desseado; pero aprovechó poco: que Solino y Estrabón dizen que se 
llamava Heróstrato; y aun era refrán entre los antiguos, quando alguno procurava de ser conoscido y señalado en algún vicio y mala hazaña, dezir «la fama de Heróstrato». Y por cosa notable se puede escrevir que, el mismo día que este templo se quemó, nació Alexandre Magno, rey de Macedonia, que sojuzgó a toda Asia: auctor es Plutarco, en la vida del mismo; y Cicerón, en el segundo libro de La naturaleza de los dioses, lo dize dos vezes; y él mismo, en el De divinatione, donde cuenta que, quando ardió este templo, luego los magos adevinaron la destruyción de toda Asia, como después la sojuzgó Alexandre”. (Mejía, Silva de varia lección II, pp. 249-250).

(e) Cuestiones médicas. El cuerpo humano en toda su dimensión es una fuente de curiosidades. Gelio se refiere muchas veces a hechos propios de la naturaleza humana, muy cercanos en este sentido a los que refiere Plinio el Viejo en el libro VII de su Historia natural. Así lo vemos en la referencia a la edad climatérica, donde Mejía pone en relación los dos lugares donde Gelio escribe a este respecto (Gel. 3, 10 y Gel. 15, 7):

"De manera que, como Marsilio Ficino en el libro segundo de Triplici vita, y Censorino en el libro De die natali, y Aulo Gelio en el tercero, cuentan, todos las hebdómadas y setenarios de años principalmente tenían por de mayor alteración, y tenían que era imposible passar sin algún grande peligro o trance o mudança en la vida o estado o salud y complisión. Y, por esto, el seteno y catorzeno y veynte y uno y veynte y ocho y treynta y cinco y quarenta y dos, y assí cada siete años, se regalavan y guardavan y tenían por peligrosos.

$\mathrm{Y}$, porque el número de tres tienen también por de gran misterio, quando se compone el siete por tres, como el veynte y uno, teníanlo aún por de más importancia, y el año quarenta y nueve, porque es de siete vezes siete, por en grande manera peligroso. Pero el de más mysterio y más temido de todos era el año sessenta y tres, porque, como veynte y uno se compone de tres vezes siete, el sessenta y tres se haze de tres vezes veynte y uno y de nueve vezes siete, que todos son en números muy celebrados. Por lo qual, quando un hombre llegava a esta hedad, él tenía grande cuydado y vigilancia en su vida y todos estavan esperando qué sería dél. Y assí lo encaresce muy mucho Julio Fírmico en su Astrología. Y Aulo Gelio, en este propósito, en el libro XV, pone una carta del emperador Octaviano, que, aviendo escapado y passado deste peligroso año, escrive a Cayo, su sobrino, hablándole en ella y significándole el plazer grande que tenía de aver ya él entrado en sessenta y quatro años, y que bien creýa dél que avría celebrado con grande plazer su nascimiento. De manera que este año de sessenta y tres temían mucho y veýan por experiencia que morían muchos hombres que llegavan a esta hedad o llegavan a punto de muerte". (Mejía, Silva de varia lección I, p. 532).

Hay otros aspectos que también son pertinentes, como esta noticia relativa a la estatura (Gel. 3, 10, 10) o al origen del nombre del dedo corazón (Gel. 10, 10) recogidas por Mejía:

"Y destos tales pies deve tener seys el hombre de buena altura, el que llegasse a siete pies sería muy alto, y de aý adelante ninguno passa que no sea gigante y mostruoso, según regla del sapientíssimo Marco Varrón: refiérelo Aulo Gelio, libro tercero. Y aun concuerda con esto lo que Suetonio dize en la vida de Octaviano, hablando de su estatura: que era mediano de cuerpo, pero no tanto que se 
paresciesse sino quando se llegava a alguno que fuesse alto; y dize que su medida era cinco pies y un dodrante (que son nueve partes de doze); por donde se vee que todo lo menos de seys pies era tenido por mediano. Este tamaño y disposición parescióles que era justo y conviniente a los ya dichos autores". (Mejía, Silva de varia lección I, pp. 653-654)

"Plinio le paresce que fue esto, en su principio, comedimiento y vergüença, como de cosa que parescía excesso y muy demasiada curiosidad traer anillo, y que, porque en la mayo yzquierda se podría traer más escondido, se ponía en ella; porque dize él que, si nosotros queremos dezir que fue por no impedir ni embaraçar la derecha para la guerra, que el mismo inconveniente ay en la yzquierda con el escudo, que en ella anda. A otros les paresce que fue esto para traer más seguras las piedras de los anillos, porque de aquella mano se usava menos comúnmente; y que en ella se escogió aquel dedo por más dispuesto y menos ocupado en el uso de la mano. Macrobio, que pone esta opinión y también la de Plinio, pone otra (Saturnales, libro 7), y es dezir que, desde el coraçón [a] aquel dedo, desciende un nervio o vena y acaba allí; y, por honrra del coraçón, paresció que merecía coronar aquel dedo con corona de oro. Aulo Gelio (libro 10) conforma con él”. (Mejía, Silva de varia lección II, p. 306).

No faltan curiosidades varias, como este remedio musical para los dolores de ciática (Gel. 4, 13), o las causas para saber cómo nace, por ejemplo, el hambre (Gel. 14, 3):

"Y, como deximos de la bívora según Teophrasto, Aulo Gelio, en el libro quarto, dize [que] la música amansa los dolores de ciática y de la gota; y también refiere lo ya dicho de la bívora". (Mejía, Silva de varia lección II, p. 88)

"Pero sin caudal no sé cómo se ha de sustentar en el ayre esta reformación de pobres, no siendo casa de Ysopete ni çancarrón de Mahoma; salvo si no se remedia con lo que Erasístrato médico griego cuenta, según refiere Aulo Gelio. Que la hambre nace de estar abiertas y estendidas las fimbrias de los intestinos y vazío el vientre y la concavidad del estómago". (Toro, Tesoro de misericordia divina y humana, fol. XLr).

Es importante el asunto relativo al estado de preñez hasta los trece meses (Gel. 3, 16), que implica un complejo problema de cómputo:

"Otros philósophos han sentido que una muger puede andar preñada hasta los treze meses. Y porque querer referir las opiniones de todos, que son muy diversas, sería nunca acabar, quien quisiere satisfazerse, vea a Aristóteles y a Aulio Gelio, y a otros muchos auctores médicos que lo tratan copiosamente, que para nosotros basta lo que aquí avemos dicho en materia que tan pocas vezes acaesce tener necessidad de saberla ni entenderla". (Torquemada, Jardín de flores curiosas, pp. 526-527).

(f) Sucesos naturales y extraordinarios. En este asunto, de gran atractivo para cualquier lector, debemos hacer la salvedad de las prevenciones que el propio Gelio expresa acerca de lo ridículo de algunos hechos extraordinarios o mirabilia. No obstante, hay hechos de este tipo que guardan también importantes enseñanzas morales, como éste de Androcles y el león (Gel. 5, 14), 
uno de los episodios más conocidos de la obra de Gelio, por lo que no es de extrañar que tanto Guevara ${ }^{16}$ como Mejía lo relaten:

"De [fol. 43] muy buena voluntad condescendió el emperador Thito a lo que el pueblo le rogó y Andrónico le pidió y así fué que dende en adelante se andaban juntos él y el león por todas las calles y tabernas de Roma, ellos se holgando y todo el pueblo con ellos se regocijando. A manera de un asnillo trahía Andrónico a su león atado con una cuerda, y cinchado con una albarda, encima de la cual traía unas talegas llenas de pan y otras cosas que les daban por las casas y tabernas, y aun otras veces consentía que subiesen encima del león los mochachos, porque le diesen algunos dineros. A los extrangeros que de tierras extrañas venían de nuevo a Roma, y no habían visto ni oído aquella historia como pasaba, si preguntaban qué cosa era tan nueva y tan monstruosa aquélla, respondíanles que aquel hombre era médico de aquel león y aquel león era huésped de aquel hombre.

Cuenta esta hystoria Aulogelio latino, y más ad longum Apio el Griego" (Guevara, Epístolas familiares I, ep. 28, p. 163).

"Apión, griego (según refiere Aulo Gelio en el catorzeno libro de sus Noches áticas), como testigo de vista escrive (y también lo affirma Eliano en el Libro de los animales) que, en unas fiestas que se hizieron en Roma muy solemnes, donde en la plaça o circo, que llamavan el Máximo, se echavan muchas bestias fieras (leones y onças y otras bestias bravas), y allí [se] echavan esclavos y otros hombres condenados a muerte para pelear con ellos, que muriessen o se deffendiessen varonilmente (espectáculo y fiesta, por cierto, de mucha crueldad), acaesció, pues, [que], entre los otros hombres que allí fueron echados, fue uno llamado Androclo, esclavo de un cónsul; y, entre los animales que acaso estavan en la plaça, avía un león grandíssimo y fiero, traýdo de Áffrica, en quien todos tenían puestos los ojos. El qual león, como Androclo fue echado cerca de donde estava, puso los ojos en él y estuvo un rato parado, mirando". (Mejía, Silva de varia lección I, pp. 543-544).

Debe hacerse notar que Mejía se equivoca al hablar del "catorzeno libro", ya que en realidad es al capítulo a lo que se refiere. La historia del caballo "Seyo" (Gel. 3, 9) es tan extraordinaria que Guevara acude a la autoridad de los antiguos que la transmitieron para legitimarla:

"La historia deste caballo Seyano escriben muy graves auctores; es a saber: Gayo Bassiano, Julio Modesto y Aulo Gelio, en el tercero libro que hizo de las Noches de Athenas; y alego estos auctores porque nadie piense que es fábula compuesta, sino que en realidad de verdad pasó como aquí contaremos la historia”. (Guevara, Epístolas familiares I, ep. 25, p. 142).

Al igual que la de Hércules, resulta asombrosa la fortaleza que tuvo un tal Milón (Gel. 15, 16), o la historia del hijo del rey Creso de Lidia (Gel. 5, 9):

"Escrive Aulo Gelio, en sus Noches áticas (y Valerio Máximo también lo cuenta), [que,] de una ciudad de Ytalia, llamada Crotón, que es en Calabria, fue un hombre, llamado Milón. El qual fue tan suelto y de tan grandes fuerças, que en

${ }^{16}$ Para la deuda que Montaigne contrae con Guevara en lo que respecta a este episodio cf. Heath 2008, p. 314. 
todos los juegos y luchas públicas nunca hallava ygual y las más destas vezes salía por vencedor; y fue coronado y dado por el más valiente y de las mayores fuerças; $\mathrm{y}$, por esto, era en todas partes conoscido y nombrado. El qual, siendo hombre ya de edad, caminando acaso por una montaña y apartándose por su passatiempo del camino, entre otros muchos vio un alcornoque que tenía dos ramos grandes y, a la juntura de los ramos, estava començado ya algo a abrir. Y el Milón parece ser que quiso provar allí sus fuerças; metiendo las manos por la hendedura, devió de querer acabar lo començado y dividir la una rama de la otra". (Mejía, Silva de varia lección I, p. 343).

"Escrive Herodoto un maravilloso caso acaescido en un hijo del rey Creso de Lidia, y por tal lo refiere Aulo Gelio; de manera que, pues tales auctores se precian de ponerlo por notable, no será perdido trabajo que yo lo cuente con lo que, al propósito, la memoria me offresciere de lo que en otras partes he leýdo". (Mejía, Silva de varia lección, I, p. 481).

El tema del destino y la adivinación también suscita el interés de Gelio y, por supuesto, el de sus lectores modernos. Así lo vemos ya desde la propia definición de lo que es el destino o "hado" (fatum) según Crisipo (Gel. 7, 2, 1), hasta episodios como el de la sibila de Cumas (Gel. 1, 19), o el famoso discurso de Favorino contra los astrólogos (Gel. 14, 1, 35-36):

"Y assí, dize Aulo Gelio que un philósopho llamado Crisipo dezía que hado era una sempiterna y indeclinable orden y cadena de las cosas". (Torquemada, Jardin de flores curiosas, p. 764).

"La que se pone por setena en orden, es la sibila cumana, llamada Amalthea. Otros la llaman Demóphile; Suidas la llama Herópile. Llámase cumana porque morava y profetizó en la ciudad de Cumas, en Ytalia (en Campania, cerca de Bayas). Désta escrive Dionisio Alicarnáseo y Solino y Aulo Gelio y Servio, que llevó a Tarquino Superbo, rey de Roma, a vender nueve libros (aunque Suydas dize que a Tarquino Prisco), y que pidió trezientas monedas de oro por ellos; y, paresciéndole al rey excessivo el precio, no los quiso. Y ella, luego, en su presencia, quemó los tres dellos y tornó a pedir el mismo precio, por los seys que quedavan, que avía pedido por todos; $y$, paresciéndole al rey mayor desatino que el primero, se burló della. La qual luego, de los seys que quedavan, quemó los tres y dixo que, por solos los tres que quedavan, le avía de dar lo que al principio pidió por todos nueve; maravillado el rey de la determinación y confiança suya, paresciéndole que devia de aver algún grande mysterio en ellos, le dio todo el precio por los tres solos. Fueron puestos y guardados en el Capitolio y tenidos siempre en grande veneración". (Mejía, Silva de varia lección II, pp. 266-267).

"Solamente, sin perjuyzio de ninguna de las partes, quiero dezir lo que Faborino, filósofo (según que Aulo Gelio refiere dél), dezía, pretendiendo apartar a los hombes desta curiosidad y ayuda de querer saber las cosas que les han de suceder de los astrólogos, que presumen saberlas (a los quales, algunos de los antiguos llamavan mathemáticos; otros, caldeos), porque me paresció aguda razón y argumento para el propósito.

Y era desta manera; que les dezía él a los tales: «Por ninguna manera os puede ser bueno esto que hazéys, ni le devéys dar crédito ni preguntarlo. Porque dad acá estos astrólogos y adevinos; claro es que lo que los astrólogos os responderán, o ha de ser de bien y prosperidad que os han de acontescer, o de trabajo o mal. Pues hablemos de lo primero, que es de bien; y digo que, o es cierto lo que os dizen, o es mentira». (Mejía, Silva de varia lección II, p. 432). 
Los fenómenos naturales también suscitaron mucha curiosidad, como vemos en esta extensa lectura y cita que Mejía hace de Gelio cuando nos habla acerca de los vientos (Gel. 2, 22):

"Estos vientos, pues, según la parte del mundo de que corren, assí los consideraron y nombraron los antiguos y los consideramos el día de oy, assí en los nombres como en el número dellos. Pero los muy antiguos sabios y poetas tomaron esta cosa más gruessamente y no pusieron tanto número ni differencias dellos como después han hallado y particularizado los que han sucedido; porque es assí que Homero ni los que le precedieron (según Plinio y Aulo Gelio y aun Vegecio, tratando la materia de los vientos, affirman), no hallaron ni señalaron más de quatro; y éstos, según que venían y ventavan de una de las quatro partes del mundo, conviene a saber: el oriente y el poniente, el septentrión o aquilón y el mediodía, que son las más principales y señaladas dél y que no ay quien no las entienda y conozca, celebradas por David (Psalmos, 106), diziendo de las regiones: «Los ayuntó del oriente del Sol, y del poniente, y del aquilón y de la mar». Las quales regiones también tocó elegantemente nuestro poeta andaluz Lucano, do dize: «Unde venit Titan et nox ubi sidera condit». (...) Y, por el lugar que el Sol se pone en el verano por junio, marcaron otro viento, que cae entre el poniente y el norte; al qual los latinos pusieron por nombre coros o cauros, y los griegos argestes, que significa «rayo» (porque su fuerça deste viento es muy grande); algunos lo llamaron apix, por venir de hazia un cabo de Ytalia, nombrado assí; y otros, olimpias; y agora, en Ytalia, maestro; en España, norueste. Con estos ocho vientos solos, se contentaron algunos; y Aulo Gelio a solos éstos pone nombre y señal". (Mejía, Silva de varia lección II, pp. 519-526).

Acorde con tales fenómenos está también la noticia sobre la fiestas devotas cuando temblaba la tierra (Gel. 2, 28):

"Pero esto en quanto a ser aquél el principio desta denominación, no lleva camino, porque Aulo Gelio escrive que sacrificavan los romanos y hazían fiestas devotas quando temblava la tierra, o avía eclypsi, sin nombrar Dios ninguno, porque no sabían si era dios o diosa el que hazía aquellas operaciones, y avían miedo (según Ammiano) que se indignasse el Dios que las causava, si nombrassen otro por él". (Toro, Tesoro de misericordia divina y humana, fol. CXVIIIv).

Finalmente, cabe destacar por su importancia simbólica el comentario sobre la proverbial fortaleza de la palma (Gel. 3, 6):

"Mas por qué aya tenido esta significación la palma más que otro árbol, escriven los antiguos que fue la causa una maravillosa propriedad de la madera della, la qual, sin ser esperimentada, la auctoridad de los que la escriven la hazen tener por cierta; los quales son Plinio en el libro diez y seys, y Aristótiles en sus Problemas, y Teophrasto en el quinto, Aulo Gelio en el tercero, y Plutarco en sus Simposíacos. Todos los quales escriven y affirman que la madera y vigas que de la palma se hazen, si la apremian con peso o carga excessiva y demasiada, assí como todas las otras maderas se avigan y abaxan para abaxo, venciéndose y sojuzgándose de la carga y peso, la madera de la palma, por el contrario, siendo assí cargada demasiado, resiste al peso y, contra él repugnando, se encorva y entuerta para arriba y se haze como arco hazia la carga. Por esta causa, pues, dize Plutarcho y Aulo Gelio que, pues el que venció a otro no se dexó vencer del miedo ni pe- 
ligro ni se enflaquesció en él (antes, resistiendo y trabajando, alcançó la victoria), el tal fue notado y señalado con el árbol que naturalmente tiene la semejante propriedad de vencer y resistir a la carga. De manera que de aquí paresce vino dar palma a los vencedores". (Mejía, Silva de varia lección I, p. 458-459).

La complejidad de la interpretación (no siempre acertada) de este capítulo ha sido estudiada por Holford-Strevens (2008) hasta su plasmación gráfica en el emblema XXXVI de Alciato ${ }^{17}$ :

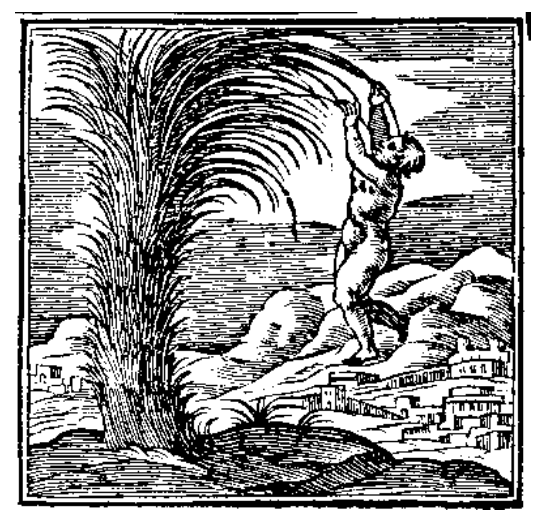

Tras analizar la anterior variedad de citas, podemos decir que es posible conformar una antología de Gelio a partir de su propia presencia en la literatura española del siglo XVI:

(a) Aforismos y enseñanzas, con frases como "la verdad es hija del tiempo" o el uso de la palabra humanitas.

(b) Filósofos griegos (Demócrito, Demóstenes, Platón, Aristóteles) y latinos (Favorino).

(c) Cuestiones lingüísticas, menos frecuentes.

(d) Historia e instituciones, con intereses varios sobre historia e instituciones romanas y sucesos de la Antigüedad.

(e) Cuestiones médicas relativas a la edad, la estatura, el hambre o la preñez.

(f) Sucesos relativos a hechos extraordinarios, al destino y fenómenos naturales.

Es posible, pues, hacerse una idea de los asuntos diversos tratados en las Noches áticas sin necesidad de haber leído la obra original. La obra latina, pues, ha reunido temas diversos entre sus páginas que al cabo del tiempo han vuelto a diseminarse.

${ }^{17}$ Para la ilustración y la traducción castellana del emblema en cuestión véase Alciato 1975, p. 77 y p. 309. Sobre la fortuna de este tema en la emblemática cf. Henkel y Schöne 1996, pp. 191-194. 


\subsection{Comentario: deleite y autoridad}

Si bien Gelio es un autor discreto dentro de la literatura latina, puede deducirse un implícito tono elogioso cuando aparece citado por los autores españoles. La excepción, o el contrapunto, lo pone el valenciano Luis Vives, que hace una sonada crítica al autor de las Noches áticas en su obra De tradendis disciplinis:

Sunt in his duabus linguis auctores quidam misti, qui simul et historias, et fabulas, et vocum significatus, et oratoria, et philosophica attingunt; quorum appellatio vera est et maxime propria philologi: hujusmodi sunt in Graeca Suidas et Athenaeus, in ambabus Aulus Gellius, homo rhapsodus plane, congestor potius quam digestor, et ostentator, quam peritus; loquaculus sine eruditione, in verbis ac sententiis putidulus; quae de significatu vocum disserit, sunt frivola et plerumque imperita, ac falsa; legendus est quidem, sed ita, ut te rem levem scias inspicere; sanior est aemulus ejus Petrus Crinitus. (De tradendis disciplinis liber III, 8 [Vives 1785, p. 337]).

"Hay en estas dos lenguas algunos escritores mixtos que tratan al tiempo de sucesos históricos, de fábulas, de significados de voces, de oratoria y de filosofía, cuyo nombre verdadero y más propio es el de filólogos. De tal índole son en griego Suidas y Ateneo. En una y otra lenguas, Aulo Gelio, auténtico rapsoda, que compila más que ordena, ostentador de conocimientos más que sabio de veras, parlanchín sin erudición, afectado en dicción y pensamientos. Sus disertaciones sobre significación de palabras son frívolas y de costumbre imperitas y falaces. Has de leerlo, sin duda, pero sabedor de que tienes tus ojos en cosa fútil y vana. Más sano que él es su émulo Pedro Crinito". (Vives 1997, pp. 131-132. Trad. de C. Porcar).

La crítica $^{18}$ viene motivada por un ingenuo sentido patrio, ya que Gelio había criticado de manera despiadada al hispano Séneca ${ }^{19}$. La cuestión no habría pasado de lo meramente anecdótico si el hecho no hubiera quedado magnificado cuarenta y ocho años después de la muerte del mismo Vives. Fue entonces cuando el editor galo Stephanus dedicó duros comentarios al humanista valenciano en sus Noctes Parisinae, dentro de su edición de Gelio (Stephanus 1585), y vemos cómo la crítica se vuelve a repetir ya a comienzos del siglo XVII en la edición ginebrina de 1609:

Nunc autem mihi de hoc saltem gratulari licet quod hanc Noctium Atticarum editionem digno (uti dixi) ac non ei dicavi, in quem illa ipsa iactari proverbia possent, quae Gellius in eos iactat quos earum lectione arcet: haec inquam, Nihil cum fidibus graculo, Nihil cum amaracino sui. Contra vero eventurum erat istud,

\footnotetext{
${ }^{18}$ También cabe citar: "Gellius durissimarum elegantiarum affectator" (Vives, 1785: 340).

${ }^{19}$ Holford-Strevens 2005, p. 329 n. 2 (p. 237 n. 2): “(...) Vives who, to avenge his compatriot Seneca, reviles him as a mere compiler and show-off, an unlearned chatterbox with a disgusting style, whose semantic discussions are footling and mostly false. Neither of these judgements is acceptable”. Cf. también Heath 2008, p. 297.
} 
si hoc dignatus honore fuissem aliquem eorum quos Ludovicus Vives sua de his Noctibus tam malefica quam malevola censura fascinavit, quorum e numero unum, magni alioqui nominis virum, in aurem, quum voles, nominabo. O quid malevolentia, quid vindictae cupiditas non audet! Itane Aulum Gellium, tantum virum, tan bene de omni fere literarum genere meritum, a Ludovico Vive, Hispano quidem illo, sed tamen (si Latinae linguae puritatem excipias) bene literato, tam male tractari? (Stephanus 1609, pp. 3-3r).

"Ahora, no obstante, puedo felicitarme por haber dedicado la presente edición de las Noches áticas a alguien digno (como dije) y no a uno a quien podrían lanzarse los mismos proverbios que Gelio arroja contra aquellos a los que desea apartar de la lectura de su obra, a saber, que la flauta no es para el grajo ni la mejorana para el cerdo. Por contra, hubiera resultado desfavorable en caso de haber dignado con este honor a algunos de esos a los que Luis Vives fascinó con su malvada y malévola censura de las Noches, entre los cuales hay uno, por lo demás varón de gran renombre, que te diré al oído cuando quieras. ¡Oh, de qué no es capaz la malevolencia, de qué no lo es el deseo de venganza! ¿Es así que Aulo Gelio, varón tan señalado, que ha prestado tan grandes servicios a casi todos los géneros literarios, sea tan maltratado por Luis Vives, un hispano ciertamente, pero, sin embargo, tan bien instruido (si exceptúas la pureza de su lengua latina)?".

Stephanus recurre también al argumento patriótico, de manera que escribe como súbdito galo contra el autor español y, en general, contra lo español (Amabam Hispaniam (quatenus et quantum a vere Gallo amari Hispania potest). Más allá de esta sonada crítica, es interesante que veamos los distintos juicios de valor, por pequeños y sutiles que sean, que se desgranan en las referencias que venimos estudiando. Gelio es escritor curioso, según lo vemos caracterizado por Guevara al referirse a la cuestión de aquello a lo que llamaban los antiguos "ladrón" (Gel. 1, 18):

"Aulo Gelio, en el libro octavo, es el que más en esta materia metió la mano, como es escriptor curioso, y de peregrinas antigüedades muy antiguo. Pone este auctor muchas maneras de ladrones, y aun muchas maneras de castigos, los cuales, aunque se cometan agora, son tenidos por culpas, mas no por hurtos". (Guevara, Epístolas familiares I, ep. 56, p. 351).

No sabemos, sin embargo, a qué se refiere Guevara cuando habla del "libro octavo", pues este es el libro que precisamente se ha perdido de los veinte que componen las Noches áticas (García Jurado 2007a, p. 34). Este error puede ser un indicio de que en realidad no ha utilizado el texto de Gelio de manera directa, dado que en ese caso hubiera caído fácilmente en su error. Vamos a señalar ahora algunos juicios implícitos sobre Gelio y la miscelánea que hemos ido encontrando en nuestro repaso de las citas. Cabe comenzar con esta referencia a Gelio "y otros de más autoridad", hecho que implica una jerarquización de los autores antiguos. Así lo vemos en un texto de Mejía sobre la mentira (Gel. 11, 11) que hemos citado ya más arriba:

"Pero, porque no todos lo entienden bien, declaremos agora la diferencia y distancia que puede aver entre dezir mentira y mentir, y en quántas maneras puede 
ser, pues Aulo Gelio y otros de más autoridad se preciaron de tratarlo y es cierto que no es siempre todo uno". (Mejía, Silva de varia lección II, p. 483).

Uno de los temas básicos de la pedagogía humanística es el de la enseñanza en relación con el deleite, asunto que no es ajeno a la obra de Gelio, releída en este sentido como obra humanística:

"Todos tuerçen la ley de su obligaçión. Y porque tengo entendido el común gusto de los hombres, que les aplaze más leer cosas del donaire: coplas, chançonetas y sonetos de placer, antes que oír cosas graves, prinçipalmente si son hechas en reprehensión, porque a ninguno aplaze que en sus flaquezas le digan la verdad, por tanto, procuré darles manera de doctrinal abscondida y solapada debajo de façiçias, fábulas, novelas y donaires, en los cuales, tomando sabor para leer, vengan a aprovecharse de aquello que quiere mi intinción. Este estilo y orden tuvieron en sus obras muchos sabios antiguos endereçados en este mesmo fin. Como Ysopo y Catón, Aulo Gelio, Juan Bocacio, Juan Pogio florentín; y otros muchos que sería largo contar, hasta Aristóteles, Plutarco, Platón. Y Cristo enseñó con parábolas y exemplos al pueblo y a sus discípulos la doctrina celestial". (Villalón, El Crótalon de Cristóforo Gnofoso, pp. 83-84).

Sin embargo, el deleite que producen ciertos asuntos puede dar la impresión de que son cosas de poca importancia, como aduce Mejía:

"Ay algunas cosas escriptas, que, aunque ellas sean y parezcan de poca importancia, por ser ingeniosas y manjar de agudos ingenios, será bien dezirlas para que en ellas se exerciten. Entre las quales es una, la que agora quiero contar, que escrive Aulo Gelio en el libro primero de sus Noches áticas, y Apuleyo también, en sus Floridos, lo cuenta". (Mejía, Silva de varia lección I, p. 338).

No debemos olvidar tampoco el importante asunto de la erudición considerada como vanidad que encontramos en Guevara:

"Ocúpense los hijos de vanidad muchos años en las academias, y allí deprendan rethórica, exercítense en philosophía, lean a Platón, oyan a Aristóteles, deprendan de coro a Homero, estudien en Cicerón, escudriñen a Tolomeo, ocúpense en Xenophón, escuchen a Tito Livio, no olviden a Aulo Gelio y sepan a Ovidio; que yo digo y afirmo que no podemos dezir que sabe poco el hombre que sabe conocer a sí mismo". (Guevara, Reloj de príncipes III, 32, p. 856).

Este texto podría entenderse ya como precursor del ensayo de Montaigne, donde prima sobre la erudición el délfico mandato de conocerse a sí mismo, es decir, de convertirnos nosotros mismos en materia de conocimiento. Precisamente son estos factores cualitativos los que apuntan hacia la escritura ensayística como reacción a la propia acumulación que supone la miscelánea, asunto que nos lleva por sí mismo al siguiente apartado, dedicado precisamene a la complejidad de la moderna relectura. 


\subsection{Relectura: el "yo" y la "variedad"}

Tras este recorrido por lecturas variadas de Gelio en los autores del XVI cabe preguntarse cuál es la consideración de la obra como tal, para qué se lee, por qué cobra en el siglo XVI más vigencia de la que jamás había tenido o de la que jamás volvería a tener. En este sentido, la miscelánea de Gelio puede releerse en calidad de "facecia", muy acorde con la pedagogía humanística, como hemos tenido ocasión de ver en un texto citado en el epígrafe anterior (Villalón, El Crótalon de Cristóforo Gnofoso, pp. 83-84). No debemos perder tampoco de vista la relectura de ciertos episodios en calidad de "galán cuento":

"Para confusión de los quales quiero contar un galán cuento que Aulo Gelio, en sus Noches áticas, y Macrobio, en sus Saturnales, escriven, que passa desta manera”. (Mejía, Silva de varia lección, I, p. 199).

Pero no cabe duda de que la clave de lectura más productiva viene dada a partir del nuevo esquema genérico que da lugar a las silvas y misceláneas humanísticas, precisamente el factor que supone el renacimiento de Gelio. Las "noches", según un antiguo tópico cultural que liga el saber a la luz, suponen el estudio nocturno a la luz de la lucerna, palabra emparentada con lux que, merced a una falsa etimología, vendría a relacionarse con lucubrare "pasar la noche en vela escribiendo a la luz del candil" y lucubratio "vigilia a la luz del candil", de donde obtenemos "elucubración", emparentada semánticamente con la palabra vigilia, que también adquiere su propia carta de naturaleza en el contexto de las misceláneas (García Jurado 2007b, pp. 294-296). Ya hemos señalado cómo Mejía está dando verdadero carácter metaliterario a esta palabra, evocando la Praefatio de Gelio, en el "Proemio" de su Silva de varia lección. No en vano, vemos circular algunas antiguas ediciones —en concreto, las de Henricus Stephanus- con título amplificado: Noctes Atticae, seu Vigiliae Atticae. Las noctes, pues, equivalen a lucubrationes y a vigiliae. Para poder dilucidar cuál es la naturaleza de la miscelánea cabe acudir al texto concreto que Pedro Mejía escribe al respecto:

\footnotetext{
"Y como en esto, como en lo demás, los ingenios de los hombres son tan varios y cada uno va por diverso camino, siguiendo yo al mío, escogí y hame parescido escrevir este libro assí, por discursos y capítulos de diversos propósitos, sin perseverar ni guardar orden en ellos; y por esto le puse por nombre Silva, porque en las selvas y bosques están las plantas y árboles sin orden ni regla. Y aunque esta manera de escrevir sea nueva en nuestra lengua castellana y creo que soy yo el primero que en ella aya tomado esta invención, en la griega y latina muy grandes auctores escrivieron assí, como fueron Ateneo, Víndice Cecilio, Aulo Gelio, Macrobio, y aun en nuestros tiempos, Petro Crinito, Ludovico Celio, Nicolao Leónico y otros algunos.

Y pues la lengua castellana no tiene, si bien se considera, por qué reconozca ventaja a otra ninguna, no sé por qué no osaremos en ella tomar las invenciones que
} 
en las otras y tractar materias grandes, como los ytalianos y otras naciones lo hazen en las suyas, pues no faltan en España agudos y altos ingenios. Por lo qual yo, preciándome tanto de la lengua que aprendí de mis padres como de la que me mostraron preceptores, quise dar estas vigilias a los que no entienden los libros latinos, y ellos principalmente quiero que me agradezcan este trabajo, pues son los más y los que más necessidad y desseo suelen tener de saber estas cosas. Porque yo, cierto, he procurado hablar de materias que no fuessen muy comunes ni anduviessen por el vulgo, o que ellas, de sí, fuessen grandes y provechosas, a lo menos a mi juyzio". (Mejía, Silva de varia lección, I, pp. 161-164).

Mejía asume, ahora en lengua castellana, las características de un género que tiene sus representantes antiguos en autores como Ateneo o Gelio, y encuentra su moderna encarnación en autores como Petrus Crinitus. Precisamente, veíamos antes cómo Vives declaraba preferir a éste último antes que a Gelio. Sin embargo, esta consideración del saber a la manera de "silva" va creando, poco a poco, una serie de rechazos y tensiones que darán lugar a la configuración de nuevas actitudes ante un saber entendido como mera acumulación. Una tensión muy productiva es la que puede plantearse en términos de "ayer" frente a "hoy", y que va dando lugar a la sensación de que lo ya sabido es algo superado e inerte. Por ello, debemos considerar el nacimiento de una nueva forma de concebir el saber, de subjetivarlo mediante el rechazo de la antigua erudición, entendida como algo impersonal, y de la superación de la autoridad de los autores clásicos. En algunos de los textos que hemos venido recogiendo se ha podido ver cómo se contrastaba lo que contaba Gelio en calidad de testimonio del mundo antiguo con lo que ocurría en el nuevo contexto donde se releía la obra. Lo podemos formular, por tanto, como la tensión entre el "ayer" frente al "hoy":

"Phabormo, el philósopho, maestro y amigo que fue de Aulo Gelio, dezía muchas vezes que por esso fueron tenidos en tanto los philósophos antiguos, porque avía muy pocos que enseñassen y muchos que deprendiessen. Lo contrario desto vemos agora, porque son ya infinitos los que tienen presumpción de ser maestros y son muy pocos los que tienen humildad para ser discípulos". (Guevara, Reloj de Príncipes, "Argumento", p. 70).

Así las cosas, el hecho de que termine cristalizando una forma nueva de escritura, la ensayística, precisamente como reacción a la antigua miscelánea, la vigilia o elucubración, hace posible que Gelio se pueda leer a partir de ese nuevo marco ya no sólo como autor de miscelánea, sino en términos de autor de "no-ensayo". Una primera forma de aproximarse a esta nueva modalidad de escritura es precisamente la que se encuentra en la epístola humanística de Fray Antonio de Guevara. Según Antonio Orejudo en su edición de las Epístolas familiares (Guevara 1995), a partir del Renacimiento la carta busca sobre todo la expresión de lo personal, ocupándose de cuestiones hasta entonces inabordables. La epístola literaria funda así un nuevo espacio comunicativo que terminará desembocando en la novela y el ensayo. Por tanto, y según 
nuestro criterio de concebir la lectura como un acto también creativo, cabría hacer ahora una lectura de Aulo Gelio dentro de la nueva clave ensayística. Nuestra propuesta quedó expresa en otro lugar:

“(...) la demostración más o menos feliz de la capacidad de Gelio como ensayista avant la lettre resulta estéril. Lo fundamental, en mi opinión, es tener presente que la creación moderna del ensayo ha provocado una mirada nueva sobre Gelio, en algún caso curiosa (...)" (García Jurado 2007a, p. 18).

El paso de una lectura propia de la miscelánea erudita a una lectura "ensayística" del propio Gelio, conlleva, paradójicamente, la superación del propio autor clásico, ya que el ensayo moderno comienza a rebasar la autoridad de tales autores, manteniendo con ellos una relación dialéctica. Esto explica, seguramente, la relación compleja que Montaigne mantiene con uno de sus antecesores fundamentales (junto a Plutarco y Séneca) ${ }^{20}$. Montaigne no puede citar a Gelio porque, si bien su nueva prosa ensayística debe mucho al autor latino, ésta se configura, precisamente, a partir del consciente rechazo a la miscelánea.

\section{Conclusiones}

Más que de unas conclusiones propiamente dichas debemos entender que el final de este trabajo es un punto de partida para una investigación abierta al futuro: la rica lectura de un libro de libros, como son las Noches áticas de Gelio, dentro del nuevo contexto del Renacimiento español. Hemos ensayado una lectura de la obra de Gelio en los autores españoles del siglo XVI desde cuatro parámetros: la consideración de la persona del autor latino, la cita variada de sus textos, el comentario o crítica relativo a la propia miscelánea como erudición y, finalmente, la relectura moderna de esa misma miscelánea, cuya superación conlleva el paulatino desarrollo de la literatura ensayística. A resultas de lo dicho, y volviendo a los parámetros con los que abríamos este trabajo, cabe hablar de una doble presencia de Gelio en el siglo XVI, de una parte la presencia de su obra editada y difundida entre los humanistas capaces de entender las lenguas clásicas, cuya cumbre será la edición de Stephanus de 1585, y, de otra, la antología inminente que supone la lectura, directa o indirecta, de la obra geliana en otras obras literarias de muy diverso tipo. Dentro de esa literatura cabe señalar la literatura epistolar de Fray Antonio de Gevara, el diálogo de Cristóbal de Villalón o la miscelánea de Pedro Mejía. No obstante, lo más notable y complejo del fenómeno de la relectura geliana será la propia superación que de ella se haga para dar lugar a una li-

\footnotetext{
${ }^{20}$ Para una revisión reciente de los autores antiguos leídos por Montaigne cf. García Gual 2009.
} 
teratura de carácter más personal que ensalce el presente frente al pasado y el mundo propio frente a la mera erudición acumulativa. En este punto, cabe señalar a Montaigne como lector de Guevara y Mejía, no en vano también lectores de Gelio, y hay que destacar cómo la relación de Gelio con Montaigne, lejos de ser aquél una mera fuente de éste, se vuelve una relación dialéctica y dinámica.

\section{BIBLIOGRAFÍA CITADA}

\section{Estudios}

Burke, Peter (1985). Montaigne. Madrid: Alianza Editorial.

Callejas Berdonés, María Teresa (1996). «El influjo de A. Gelio en la producción miscelánea humanística», en Mercè Puig Rodríguez-Escalona (ed.), Tradició Clàssica. Actes del'XI Simposi de la Secció Catalana de la SEEC. Andorra la Vieja: Ministeri d'Educació, Joventut i Esports, pp. 203-208.

Covarrubias Orozco, Sebastián (1994). Tesoro de la lengua castellana o española, ed. de Felipe C. R. Maldonado revisada por Manuel Camarero. Madrid: Castalia.

Cuartero Sancho, María Pilar (1981). Fuentes clásicas de la literatura paremiológica del siglo XVI. Zaragoza: Institución Fernando el Católico.

García Gual, Carlos (2009). «Sobre los Ensayos de Montaigne y sus precursores», Estudios clásicos 135 , pp. 77-90.

García Jurado, Francisco (2007a). Aulo Gelio. Noches áticas. Antología, Francisco García Jurado (ed.). Madrid: Alianza Editorial.

García Jurado, Francisco (2007b). «Símiles y metáforas de la erudición en Aulo Gelio», Emerita. Revista de Filología Clásica 75/2, pp. 279-298.

García Jurado, Francisco (2008). «La peculiar fortuna de Aulo Gelio en la moderna Literatura argentina», Argos, 32, pp. 47-65.

Gómez, Jesús (1996). El ensayo español. Vol. 1. Los orígenes: siglos XV a XVII, Jesús Gómez (ed.), José-Carlos Mainer (prol.). Barcelona: Crítica.

Heath, Michael (2008). «Gellius in the French Renaissance», en Leofranc Holford-Strevens y Amiel Vardi (eds.), The Worlds of Aulus Gellius. $2^{\mathrm{a}}$ ed. Oxford, Oxford University Press, pp. 282-317.

Henkel, Arthur y Schöne, Albrecht (1996). Handbuch zur sinnbildkunst des XVI und XVII Jahrhunderts, Arthur Henkel y Albrecht Schöne (eds.). Stuttgart-Weimar: Metzler Verlag.

Holford-Strevens, Leofranc (2005). Aulus Gellius. An Antonine Scholar and his Achievement. Revised Edition. Oxford: Oxford University Press.

Holford-Strevens, Leofranc y Amiel Vardi, ed. (2008). The Worlds of Aulus Gellius. Oxford: Oxford University Press.

Holford-Strevens, Leofranc (2008). «Recht as een Palmen-Bohm and Other Facets of Gellius' Medieval and Humanistic Reception», en Leofranc Holford-Strevens y Amiel Vardi (eds.), The Worlds of Aulus Gellius. Oxford: Oxford University Press, pp. 250-281.

Ker, James (2004). «Nocturnal writers in imperial Rome: the culture of lucubratio», CPh., 99, pp. 209-242.

Lerner, Isaías (1992). «Poética de la cita en la Silva de Pero Mexía: las fuentes clásicas», en Antonio Vilanova (ed.), Actas del X Congreso de la Asociación Internacional de Hispanistas, Barcelona 21-26 de agosto de 1989. Vol. I. Barcelona: PPU, pp. 491-500 disponible en la dirección electrónica 
http://cvc.cervantes.es/obref/aih/pdf/10/aih_10_1_056.pdf (consultado el 23 de noviembre de 2009).

Luck, George (1958). «Scriptor classicus», Comparative Literature, 10, pp. 150-158.

Marache, René (2002). «Introduction» a Aulu-Gelle, Les nuits Attiques, vol. I. París: Les Belles Lettres.

Menéndez Pelayo, Marcelino (1950). Bibliografía hispano-latina clásica. vol. III. Santander: Aldus.

Vardi, Amiel (1993). «Why Attic Nights or What's in a Name?», $C Q$, 43, pp. 298-301.

Villey, Pierre (1908). Le sources et l'évolution des Essais de Montagne I, París: Hachette.

\section{Ediciones $^{21}$}

Alciato, Andrea (1975). Emblemas, Prólogo de Manuel Montero Vallejo, preparación y notas, Mario Soria. Madrid: Editora Nacional, 1975.

Guevara, Antonio de (1995). Epístolas Familiares, Antonio Orejudo (ed.). Madison: Hispanic Seminary of Medieval Studies.

Guevara, Antonio de (1984). Menosprecio de corte y alabanza de aldea, Asunción Rallo (ed.). Madrid: Cátedra (CORDE).

Guevara, Antonio de (2004). Obras completas. Vol. III, Epístolas familiares, Emilio Blanco (ed.). Madrid: Biblioteca Castro.

Guevara, Antonio de (1994). Relox de Príncipes, Emilio Blanco (ed.). Madrid: ABL/Conferencia de Ministros Provinciales de España.

Gronovius, Joannis Fredericus (1688). Auli Gellii Noctes Atticae cum notis et emendationibus Joannis Frederici Gronovii. Lyon: apud Ioannem de Vivié.

Mexía, Pedro (1989-1990). Silva de varia lección I-II, Antonio Castro (ed.). Madrid: Cátedra.

Montaigne, Michel de. Ensayos completos, Almudena Montojo (trad.) y Álvaro Muñoz Robledano (intr.). Madrid: Cátedra, 2003.

Pérez de Moya, Juan (1995). Philosofía secreta de la gentilidad, Carlos Clavería (ed.). Madrid: Cátedra (CORDE).

Stephanus, Henricus (1585). Auli Gellii Noctes Atticae seu Virgliae Atticae, quas nunc primum a magno mendorum numero magnus veterum exemplarium numerus repurgavit. Henrici Stephani Noctes aliquot Parisianae (e viginti septem II, III, IV, VI, VII, et VIII) Atticis A. Gellii Noctibus seu Vigiliis invigilatae. Eiusdem H. Stephani annotationes in alios Gellii locos prodibunt cum notis Ludov. Carrionis (qui vet. Exemplaria contulit) prelo iam traditis. París: Typis Hartmanni Palthenii, sumptibus heredem D. Zachariæ Palthenii.

Stephanus, Henricus (1609). Auli Gellii Noctes Atticae seu Vigiliae Atticae ad exemplar potissimum Henrici Stephani lucidiores redditae; Quas nunc primum a magno mendorum numero magnus veterum exemplarium numerus repurgavit. Ginebra: Apud Samuelem Crispinum.

Toro, Gabriel de (1999). Tesoro de misericordia divina y humana. Lina Rodríguez Cacho (ed.). Salamanca: Cilus (CORDE).

Torquemada, Antonio de (1994). Jardín de flores curiosas. Lina Rodríguez Cacho (ed.). Madrid (CORDE)

${ }^{21}$ Las ediciones citadas que van seguidas de las siglas CORDE han sido consultadas en REAL ACADEMIA ESPAÑOLA: Banco de datos (CORDE) [en línea]. Corpus diacrónico del español. <http://www.rae.es> [Fecha de la consulta: 20 de noviembre de 2009]. 
Villalón, Cristóbal de (1990). El Crótalon de Cristóforo Gnofoso, Asunción Rallo (ed.). Madrid: Cátedra (CORDE).

Villalón, Cristóbal de (1977). El Scholástico, Richard J.A. Kerr (ed.). Madrid: CSIC, 1977 (CORDE).

Vives, Juan Luis (1785). Opera omnia distributa et ordinata in argumentorum classes praecipuas a Gregorio Majansio. Vol. VI. Valencia: In officina Benedicti Monfort.

Vives, Juan Luis. De disciplinis (1997). 3 vol., M.A. Coronel Ramos et alii (trad. y com.). Valencia: Ajuntament de València, 1997.

Fecha de recepción: 14 de diciembre de 2009

Fecha de aceptación: 16 de julio de 2010 